\title{
Natural product HTP screening for antibacterial (E.coli 0157:H7) and anti-inflammatory agents in (LPS from E. coli 0111:B4) activated macrophages and microglial cells; focus on sepsis
}

\author{
Elizabeth A. Mazzio ${ }^{1}$, Nan Li', David Bauer', Patricia Mendonca', Equar Taka', Mohammed Darb',
} Leeshawn Thomas ${ }^{3}$, Henry Williams ${ }^{2}$ and Karam F. A. Soliman ${ }^{1 *}$

\begin{abstract}
Background: Acute systemic inflammatory response syndrome arising from infection can lead to multiple organ failure and death, with greater susceptibility occurring in immunocompromised individuals. Moreover, sub-acute chronic inflammation is a contributor to the pathology of diverse degenerative diseases (Parkinson's disease, Alzheimer's disease and arthritis). Given the known limitations in Western medicine to treat a broad range of inflammatory related illness as well as the emergence of antibiotic resistance, there is a renewed interest in complementary and alternative medicines (CAMs) to achieve these means.

Methods: A high throughput (HTP) screening of >1400 commonly sold natural products (bulk herbs, cooking spices, teas, leaves, supplement components, nutraceutical food components, fruit and vegetables, rinds, seeds, polyphenolics etc.) was conducted to elucidate anti-inflammatory substances in lipopolysaccharide (LPS) (E. coli serotype O111:B4) monocytes: RAW 264.7 macrophages [peripheral], BV-2 microglia [brain]) relative to hydrocortisone, dexamethasone and L-N6-(1 Iminoethyl)lysine (L-NIL). HTP evaluation was also carried out for lethal kill curves against E.coli 0157:H7 $1 \times 10^{6} \mathrm{CFU} / \mathrm{mL}$ relative to penicillin. Validation studies were performed to assess cytokine profiling using antibody arrays. Findings were corroborated by independent ELISAs and NO2-/iNOS expression quantified using the Griess Reagent and immunocytochemistry, respectively. For robust screening, we developed an in-vitro efficacy paradigm to ensure anti-inflammatory parameters were observed independent of cytotoxicity. This caution was taken given that many plants exert tumoricidal and anti-inflammatory effects at close range through similar signaling pathways, which could lead to false positives.

(Continued on next page)
\end{abstract}

\footnotetext{
* Correspondence: karam.soliman@famu.edu

${ }^{1}$ College of Pharmacy \& Pharmaceutical Sciences, Florida A\&M University, Room 104 Dyson Pharmacy Building, 1520 ML King Blvd, Tallahassee, FL 32307, USA

Full list of author information is available at the end of the article
} 
(Continued from previous page)

Results: The data show that activated BV-2 microglia cells (+ LPS $1 \mu \mathrm{g} / \mathrm{ml})$ release $>10$-fold greater IL-6, MIP1/2, RANTES and nitric oxide (NO2-), where RAW 264.7 macrophages (+ LPS 1 $\mathrm{gg} / \mathrm{ml}$ ) produced > 10-fold rise in sTNFR2, MCP-1, IL-6, GCSF, RANTES and NO2-. Data validation studies establish hydrocortisone and dexamethasone as suppressing multiple pro-inflammatory processes, where L-NIL suppressed NO2-, but had no effect on iNOS expression or IL-6. The screening results demonstrate relative few valid hits with anti-inflammatory effects at $<250 \mu \mathrm{g} / \mathrm{ml}$ for the following: Bay Leaf (Laurus nobilis), Elecampagne Root (Inula helenium), Tansy (Tanacetum vulgare),Yerba (Eriodictyon californicum) and Centipeda (Centipeda minima), Ashwagandha (Withania somnifera), Feverfew (Tanacetum parthenium), Rosemary (Rosmarinus officinalis), Turmeric Root (Curcuma Longa), Osha Root (Ligusticum porteri), Green Tea (Camellia sinensis) and constituents: cardamonin, apigenin, quercetin, biochanin A, eupatorin, (-)-epigallocatechin gallate (EGCG) and butein. Natural products lethal against [E. coli 0157:H7] where the $\mathrm{LC}_{50}<100 \mu \mathrm{g} / \mathrm{ml}$ included bioactive silver hydrosol-Argentyn 23, green tea (its constituents EGCG > Polyphenon $60>(-)$-Gallocatechin > Epicatechin > (+)-Catechin), Grapeseed Extract (Vitis vinifera), Chinese Gallnut (its constituents gallic acid > caffeic acid) and gallic acid containing plants such as Babul Chall Bark (Acacia Arabica), Arjun (Terminalia Arjuna) and Bayberry Root Bark (Morella Cerifera).

Conclusions: These findings emphasize and validate the previous work of others and identify the most effective CAM anti-inflammatory, antibacterial compounds using these models. Future work will be required to evaluate potential combination strategies for long-term use to prevent chronic inflammation and possibly lower the risk of sepsis in immunocompromised at risk populations.

\section{Background}

Global health initiatives are encumbered by a vast majority of the population suffering from non-communicable inflammatory diseases such as cardiovascular disease, neurodegeneration, diabetes, arthritis, ulcerative colitis/bowel disease and cancer. Also, with increased incidence of antibiotic resistance, acute inflammation from sepsis plays a major role in mortalities arising from diverse infectious agents [1, 2]. Given limitations in Western medicine to treat/prevent a broad range of inflammatory related illness, there is a renewed interest in complementary and alternative medicines (CAMs) to achieve these means [3-9].

While there exist a plethora of scientific publications on the efficacy of individual CAMs in specific inflammatory models, there lacks a relative comparative potency rank of the most commonly marketed CAMs in a single study, conducted under uniform conditions. Our high throughput (HTP) screening library houses over 1400 products most which are available and sold to consumers throughout the world in the form of bulk herbs, cooking spices, teas, leaves, supplement components, nutraceutical food components, fruit and vegetables, roots, rinds, seeds, polyphenolics etc. The purpose of the current study is to screen commonly utilized CAMs for anti-inflammatory efficacy under uniform standard conditions to elucidate the most potent at non-toxic/low therapeutic concentrations $(<250 \mu \mathrm{g} / \mathrm{mL})$, and further to compare these to steroidal and NSAID drugs.

The in-vitro model employed was that of monocytes (peripheral and central nervous system) stimulated by lipopolysaccharide (LPS) derived from E. coli O111:B4.
LPS is a cell wall endotoxic component from gram negative bacteria which evokes a deadly cytokine storm associated with septicemia, septic shock and multi organ failure. Known biologic consequences of LPS include the colossal release of chemotactic cytokines, IL-3 IL-12, TNF-alpha, IL-6, IL-1 beta, inducible nitric oxide (iNOS) $\mathrm{NO}_{3}-/ \mathrm{NO}_{2}$-, P-selectin, CD 11b/CD18 (Mac-1) ICAM1, PGE2 which enable massive neutrophil infiltration and hemolytic [10-13]. While many of these inflammatory molecules at high concentrations are lethal, subchronic rises of the same are associated with age related inflammatory degenerative diseases such as Parkinson's disease, Alzheimer's disease and arthritis [14-17]. Therefore, the use of LPS in this model and subsequent elucidation of the most effective CAMs against inflammatory parameters, can provide information on potential therapeutics for both chronic and acute inflammatory processes.

In this study, we conduct a HTP screening of CAMs to assess both capacity to kill a pathogenic strain of E.coli 0157:H7 as well as to mitigate the proinflammatory effects from E.Coli derived endotoxin cell wall component; LPS.

\section{Methods}

Hanks Balanced Salt Solution, (4-(2-hydroxyethyl)-1piperazineethanesulfonic acid) (HEPES), ethanol, sulfanilamide, 96 well plates, general reagents and supplies, were all purchased from Sigma-Aldrich, (St Louis, MO, USA) or VWR (Radnor, PA, USA). Imaging probes were purchased from Life Technologies (Grand Island, NY, USA). Natural products were purchased from Frontier 
Natural Products Co-op (Norway, IA, USA), Monterey Bay Spice Company (Watsonville, CA, USA), Mountain Rose Herbs (Eugene, OR, USA), Mayway Traditional Chinese Herbs (Oakland, CA, USA), Kalyx Natural Marketplace (Camden, NY, USA), Futureceuticals (Momence, IL, USA), organic fruit vegetable market: New Leaf (Tallahassee, FL, USA), Florida Food Products Inc. (Eustis, FL, USA), Patel Brothers Indian Grocery (Tampa, FL, USA), Opil Gold from Aging Sciences LLC (Wayland, MA, USA) and Colloidal Silver - Argentyn $23^{\circ}$ Natural Immunogenics (Sarasota, FL, USA). Elisa kits and cytokine antibody arrays were purchased from Assay Biotech (Sunnyvale, CA) and Raybiotech (Norcross, GA, USA).

\section{Cell culture}

BV-2 microglia (BV-2) cells were provided by Elizabeta Blasi [18], and RAW 264.7 cells were purchased from American Type Culture Collection (Manassas, VA, USA). Cells were cultured in DMEM high glucose media [glucose $4500 \mathrm{mg} / \mathrm{L}$ ] containing 5\% FBS, $4 \mathrm{mM}$ L-glutamine, and penicillin/streptomycin (100 $\mathrm{U} / 0.1 \mathrm{mg} / \mathrm{mL}$ ). Culture conditions were maintained at $37{ }^{\circ} \mathrm{C}$ in $5 \% \mathrm{CO}_{2}$ /atmosphere and every $2-3$ days, the media was replaced and cells sub-cultured. For experiments, plating media consisted of DMEM (minus phenol red) [glucose $4500 \mathrm{mg} / \mathrm{L}$ ], 2.5\% FBS and penicillin/streptomycin (100 U/0.1 mg/mL). LPS O111:B4 was prepared in HBSS at $1 \mathrm{mg} / \mathrm{mL}$ and stored at $-20{ }^{\circ} \mathrm{C}$. For experiments, LPS was added to the culture media at a working concentration of $1 \mu \mathrm{g} / \mathrm{mL}$.

\section{Bacterial culture}

A single colony of $E$. coli O157:H7 was grown on an agar plate. E. coli was then inoculated into a $20 \mathrm{~mL}$ of LuriaBertani (LB) in a flask, grown at $37{ }^{\circ} \mathrm{C}$ with moderate shaking $(180 \mathrm{rpm})$, to an OD $600 \mathrm{~nm}=0.6$. One $\mathrm{mL}$ of the culture suspension was moved into a $1.5 \mathrm{~mL}$ Eppendorf tube and centrifuged for $1 \mathrm{~min}$ at $10,000 \mathrm{~g}\left(4{ }^{\circ} \mathrm{C}\right)$. After discarding the supernatant, the bacterial pellet was re- suspended in $1 \mathrm{~mL}$ sterilized water. This centrifugation was repeated twice. The bacteria were stored at $4{ }^{\circ} \mathrm{C}$. The bacterial cell numbers were then determined using colony forming units (CFU) through serial dilution plating on LB plate at $37^{\circ} \mathrm{C}$. The experimental concentration of $E$. coli was $1 \times 10^{6} \mathrm{CFU} / \mathrm{mL}$.

\section{Sample preparation}

All natural chemicals and reference drugs were dissolved in DMSO $[5-20 \mathrm{mg} / \mathrm{mL}]$ and crude herbs in absolute ethanol $[50 \mathrm{mg} / \mathrm{mL}]$ after being diced, macerated and powdered then stored at $-20{ }^{\circ} \mathrm{C}$. All plants were

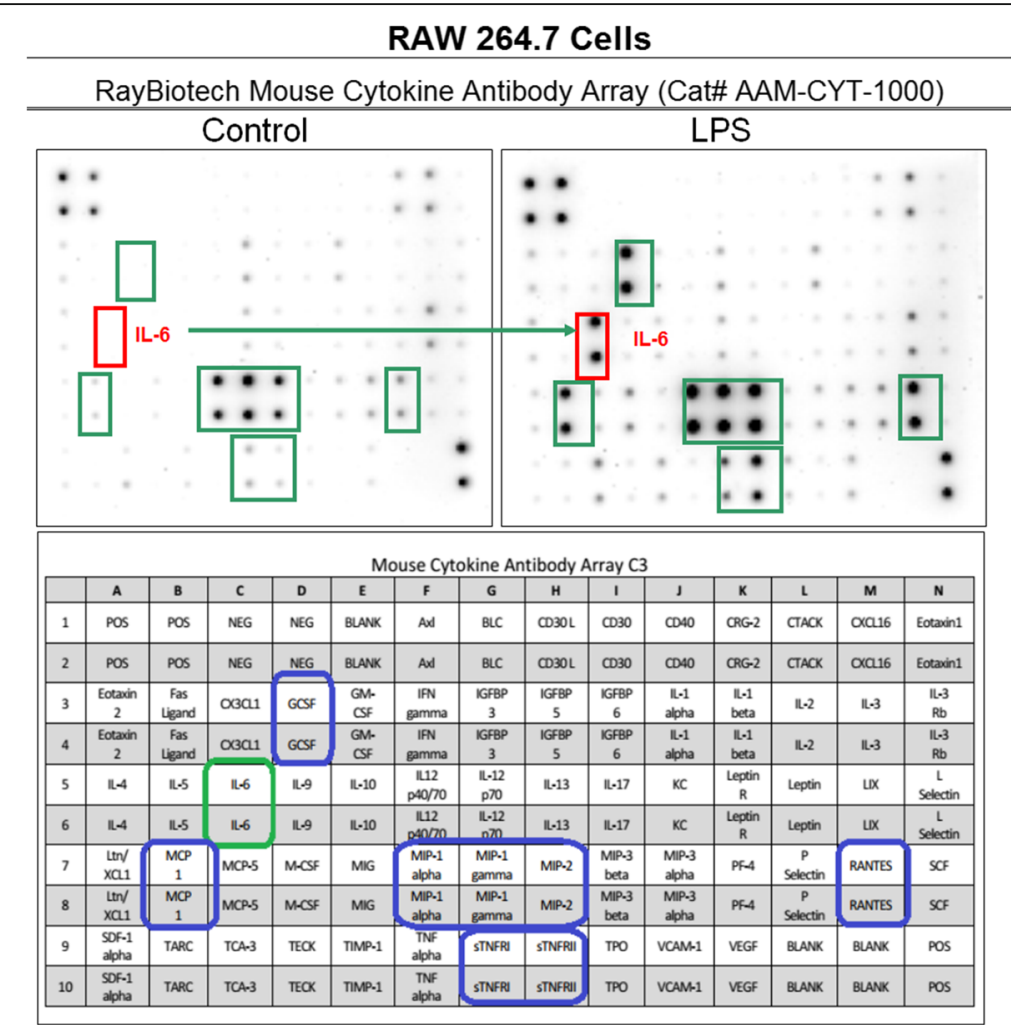

Fig. 1 Cytokine release profile in LPS activated RAW 264.7 cells. The data are displayed as the cytokine array blot image and array grid layout with leading changes presented in highlighted boxes 
cataloged by manufacturer, botanical and common names. All dilutions were prepared in sterile HBSS + 5 mM HEPES, adjusted to a $\mathrm{pH}$ of 7.4, ensuring solvent concentration of DMSO or absolute ethanol at less than $0.5 \%$.

\section{Cell and microbial -viability}

Cell and microbial viability were assessed using resazurin 7]-Hydroxy-3H-phenoxazin-3-one 10-oxide] (Alamar Blue) indicator dye [19]. A working solution of resazurin was prepared in sterile HBSS minus phenol red $(0.5 \mathrm{mg} / \mathrm{mL})$, then added $(15 \% \mathrm{v} / \mathrm{v})$ to each sample. Samples were returned to the incubator for $2-4 \mathrm{~h}$, and reduction of the dye by viable cells (to resorufin, a fluorescent compound) was quantitatively analyzed using a Synergy HTX multi-mode reader Bio-Tek Inc. (Winooski, VT, USA) with settings at [550 $\mathrm{nm} / 580 \mathrm{~nm}$, [excitation/emission].

\section{In-Vitro efficacy index}

Several methodological concerns were addressed regarding HTP screenings. These included basic controls for $\mathrm{pH}$ (neutralized with buffered HBSS) and cell viability.
In-vitro, immortal (malignant) immunocompetent cell lines such as glioma cells, macrophages, microglia, lymphocytes or granulocytes are of tumor origin, and many natural compounds simultaneously induce apoptosis in malignant cells and attenuate inflammation via the same pathways (i.e. phosphorylation of extracellular signalregulated kinase (ERK), c-jun NH2-terminal kinase (JNK) phosphorylation and mitogen-activated protein kinases (MAPK)/NF- $\mathrm{KB}$ ) [20-26]. For this reason, we constructed and utilized an in-vitro efficacy index $(i \mathrm{EI})$ paradigm, to ensure that anti-inflammatory effects are occurring at non-cytotoxic concentrations. The $i \mathrm{EI}$ is defined as the $\mathrm{LC}_{50}$ (toxic concentration)/ $/ \mathrm{IC}_{50}$ (anti-inflammatory concentration) ratio, with higher values reflecting a greater confidence in the anti-inflammatory effects occurring independently of cell death.

\section{Nitrite $\left(\mathrm{NO}_{2}-\right) / \mathrm{iNOS}$ expression}

Quantification of nitrite $\left(\mathrm{NO}_{2}{ }^{-}\right)$was determined using the Greiss reagent [27]. The Greiss reagent was prepared by mixing an equal volume of $1.0 \%$ sulfanilamide in $10 \%$ phosphoric acid and $0.1 \% \mathrm{~N}$ (1-naphthyl)-ethylenediamine in deionized water,

\section{BV2 Cells}

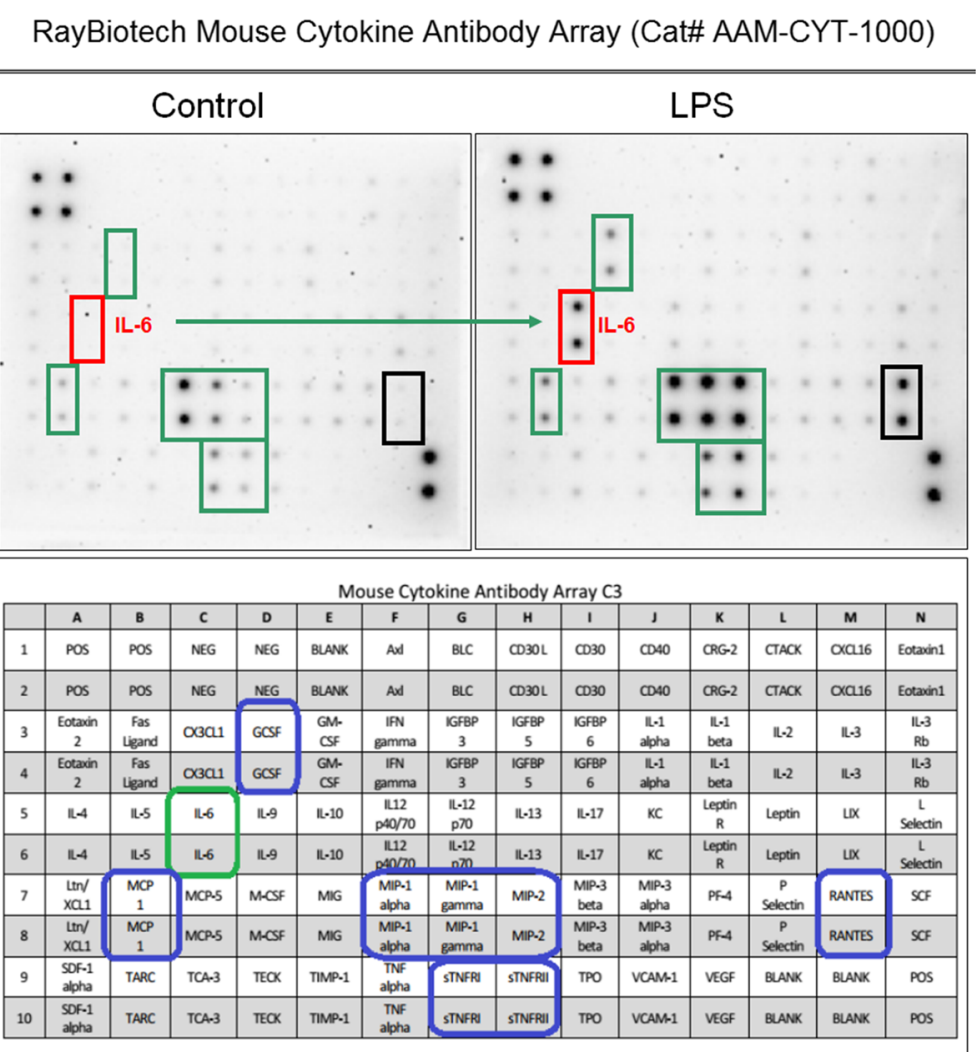

Fig. 2 Cytokine release profile in LPS activated BV-2 cells. The data are displayed as the cytokine array blot image and array grid layout with leading changes presented in highlighted boxes 
which was added directly to the cell supernatant (experimental media consisting of DMEM - phenol red) and incubated at room temperature for $10 \mathrm{~min}$. Controls and blanks were run simultaneously, and subtracted from the final value to eliminate interference. Samples were analyzed at $540 \mathrm{~nm}$ on a Synergy HTX multi-mode reader; Bio-Tek (Winooski, VT, USA).

iNOS protein expression was determined using immunocytochemistry. Cells were fixed in $4 \%$ paraformaldehyde/permeabilized in $0.2 \%$ Triton $\mathrm{X} \quad 100$ in phosphate buffered saline (PBS) and incubated with anti-iNOS, an N-Terminal antibody produced in rabbit for $24 \mathrm{~h}$ at $4{ }^{\circ} \mathrm{C}$ in a casein blocking buffer. Samples were washed in PBS, then incubated with anti-rabbit Alexa Fluor ${ }^{\ominus} 488$ conjugate for two hours at RT. Samples were counterstained with propidium iodide and imaged using a fluorescent/inverted microscope, CCD camera and data acquisition using ToupTek View ; ToupTek Photonics Co (Zhejiang, P.R.China).

\section{Mouse cytokine antibody array}

Mouse Cytokine Antibody Arrays (Product Code: AAM-CYT-1000) Ray Biotech; (Norcross, GA, USA) were used to profile the effects of LPS $(1 \mu \mathrm{g} / \mathrm{mL})$ on BV-2 and RAW 234.7 cell lines. Each experiment was carried out according to the manufacturer's instructions, and in triplicate. Briefly, antibody-coated array membranes were first incubated for 30 min with 1 $\mathrm{mL}$ of blocking buffer. After $30 \mathrm{~min}$, blocking buffer was decanted and replaced with $1 \mathrm{~mL}$ supernatant from control (untreated) samples, cells treated with (1ug/mL LPS only) and a media blank. Membranes were incubated overnight at $4{ }^{\circ} \mathrm{C}$ with mild shaking. The next day, the medium was decanted; membranes were washed, and subsequently incubated with $1 \mathrm{~mL}$ biotin-conjugated antibodies for $6 \mathrm{~h}$. Lastly, biotinconjugated antibodies were removed and membranes were incubated with HRP-conjugated streptavidin (2h), then evaluated for densitometry using a chemiluminescence substrate monitored on a VersaDoc Imager/Quantity One software from Bio-Rad: (Hercules, CA, USA).

\section{IL-6 (Interleukin-6) ELISA}

After experimental treatment, cells supernatants were directly evaluated for concentration of IL-6 using a Murine OmniKine ${ }^{\mathrm{Tm}}$ IL-6 ELISA (Product Code \# OK0187), Assay Biotechnology Inc. (Sunnyvale, CA, USA), performed according to the manufacturer's guidelines. Data was quantified by optical density at $450 \mathrm{~nm}$ using a Synergy HTX multi-mode reader from Bio-Tek (Winooski, VT, USA).
LPS stimulated release of IL-6, in BV2 and RAW264.7 Cells @24 Hours

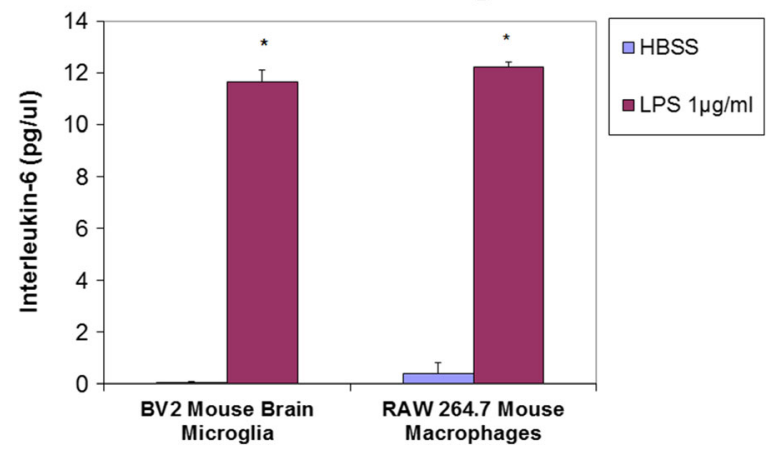

Fig. 3 ELISA: Quantification of IL-6 in the supernatant of resting and LPS activated cells (BV-2 cells, RAW 264.7 cells). The data represent $\mathrm{IL}-6(\mathrm{pg} / \mu \mathrm{l})$ and are expressed as the Mean \pm S. E. M., $n=3$. Differences between resting and LPS activated cells were determined by a student's $T$ test $\left({ }^{*}\right) P<0.001$

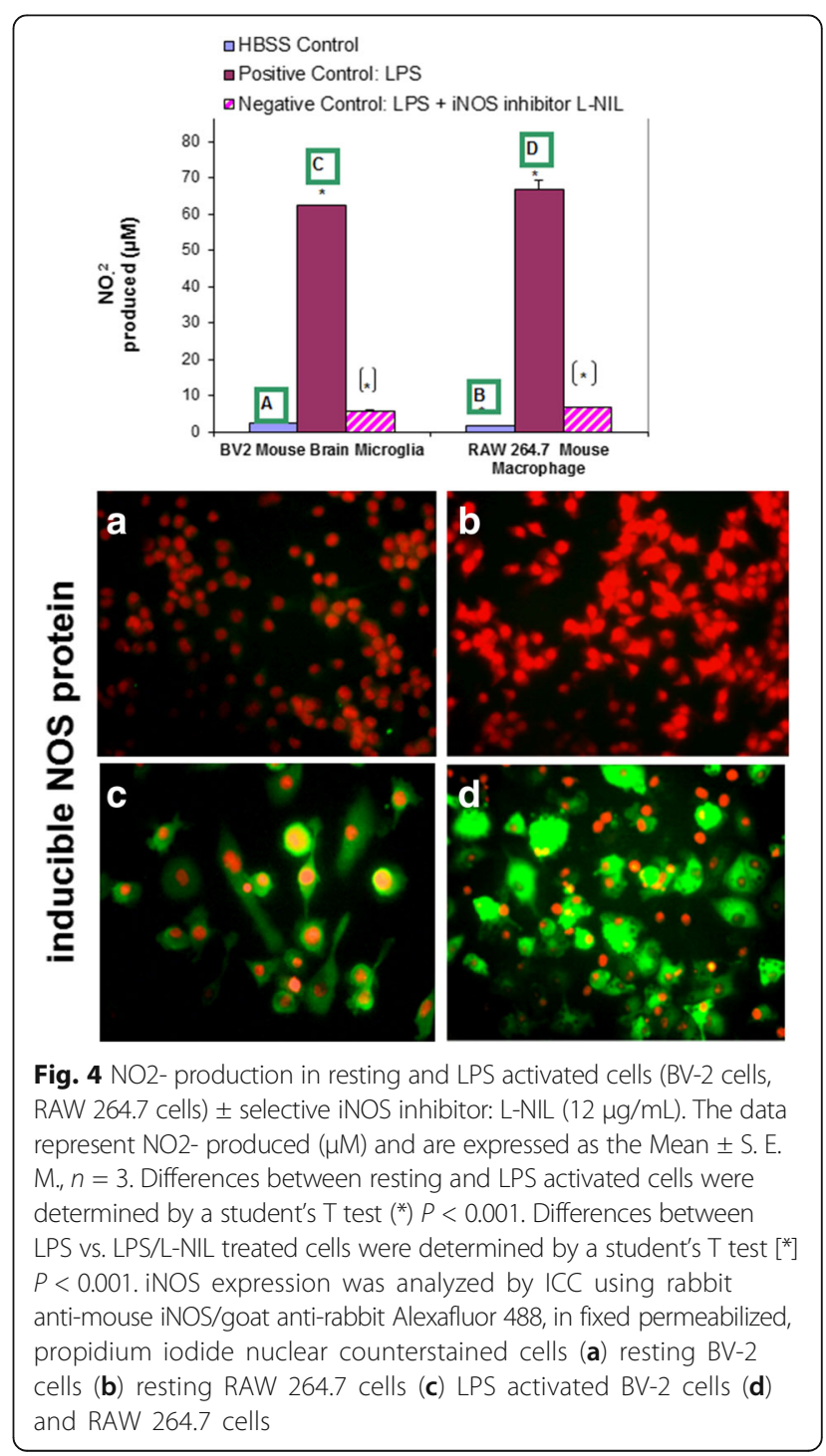




\section{Data analysis}

Statistical analysis was performed using Graph Pad Prism (version 3.0; Graph Pad Software Inc. San Diego, CA, USA) with significance of difference between the groups assessed using a one-way ANOVA then followed
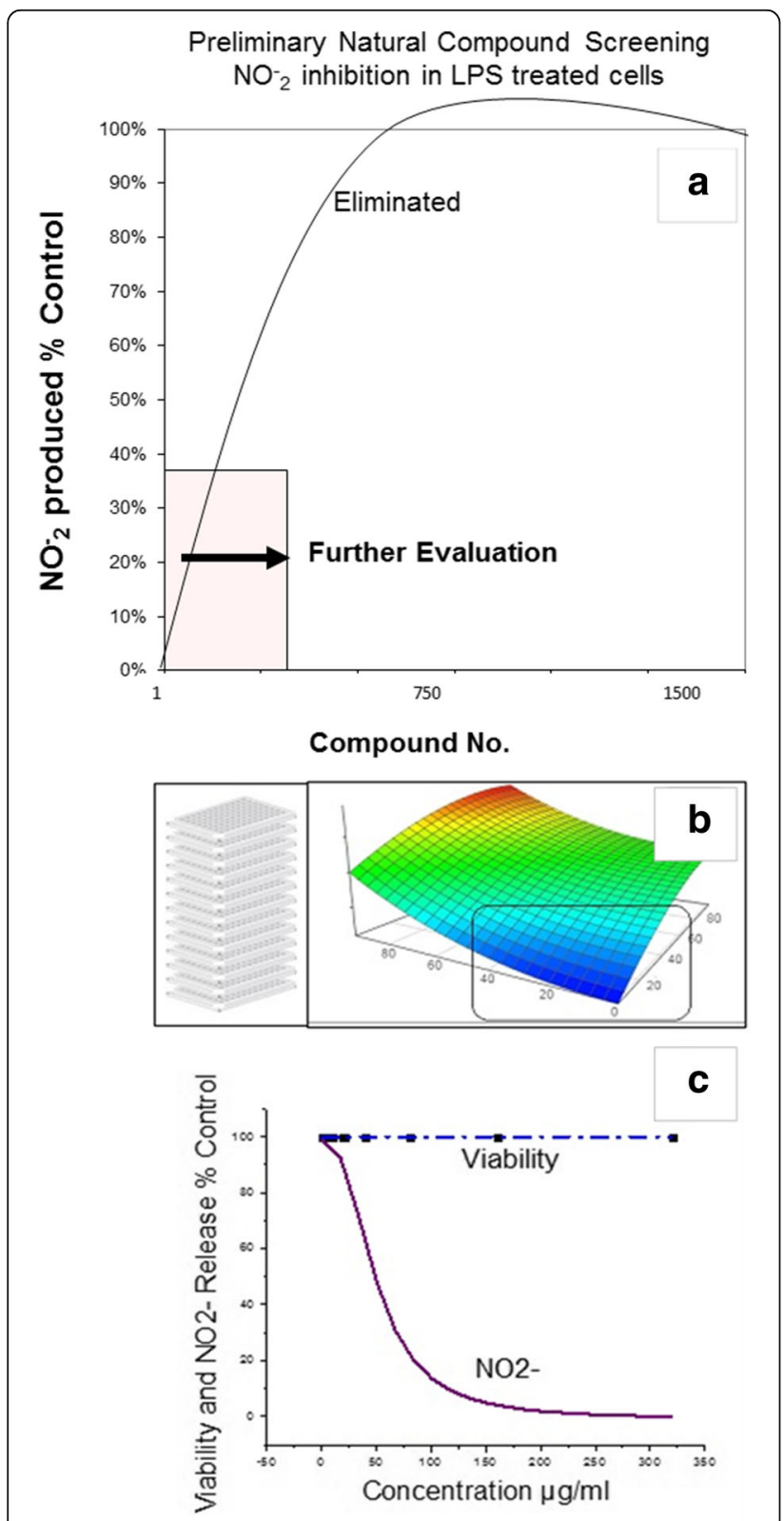

Fig. 5 High-through-put study design. The basic study layout consisted of a primary first level tier 1 screening by which all CAMs were tested to reduce $\mathrm{NO}_{2}$ - in LPS treated BV-2 and RAW 264.7 cells [maximum working concentrations were : $230 \mu \mathrm{g} / \mathrm{mL}$ (plant based) and $92 \mu \mathrm{g} / \mathrm{ml}$ (metabolites, drugs and polyphenolics)]. a, b Compounds displaying an $\mathrm{IC}_{50}$ below the 1 st tier concentrations were further evaluated as per the template (c). All compounds were simultaneously evaluated for toxicity/anti-inflammatory effects and an iEl differential was established $\left(\mathrm{LC}_{50} / \mathrm{IC}_{50}\right)$ to prevent false positives incurred by cytotoxic effects
Table 1 Efficacy of anti-inflammatory CAMS relative to cellular toxicity in LPS activated RAW 264.7 cells

\begin{tabular}{|c|c|c|c|}
\hline \multicolumn{4}{|c|}{ RAW 264.7 cells $+1 \mu / \mathrm{mL}$ LPS: anti-inflammatory potency } \\
\hline Substance & $\begin{array}{l}\text { Anti-inflammatory } \\
\mathrm{IC}_{50}(\mu \mathrm{g} / \mathrm{mL})\end{array}$ & $\begin{array}{l}\text { Toxicity } L C_{50} \\
(\mu \mathrm{g} / \mathrm{mL})\end{array}$ & $\begin{array}{l}i E I\left(L C_{50} /\right. \\
\left.I C_{50}\right) \\
\end{array}$ \\
\hline L-N-lysine dihydrochloride & 4.4 & 250.0 & $>57.4$ \\
\hline Cardamonin & 6.1 & 250.0 & $>40.8$ \\
\hline Dexamethasone & 1.6 & 260.0 & $>22.4$ \\
\hline Hydrocortisone & 45.6 & 250.0 & $>5.4$ \\
\hline Bay Leaf/Laurus nobilis & 92.6 & 537.0 & $>5.8$ \\
\hline $\begin{array}{l}\text { Tansy Herb/Tanacetum } \\
\text { vulgare }\end{array}$ & 76.7 & 934.9 & 12.2 \\
\hline Apicidin & 0.2 & 2.4 & 11.7 \\
\hline Apigenin & 30.8 & 252.0 & 8.2 \\
\hline Yerba Santa Lf/E. californicum & 194.0 & 1413.4 & 7.3 \\
\hline Butein & 8.0 & 57.9 & 7.3 \\
\hline $\begin{array}{l}\text { Ashwagandha/Withania } \\
\text { somnifera }\end{array}$ & 457.2 & 3306.0 & 7.2 \\
\hline $\begin{array}{l}\text { Centipeda Herb/Centipeda } \\
\text { minima }\end{array}$ & 213.7 & 1260.5 & 5.9 \\
\hline $\begin{array}{l}\text { Rosemary Lf/Rosmarinus } \\
\text { officinalis }\end{array}$ & 132.4 & 754.8 & 5.7 \\
\hline $\begin{array}{l}\text { Feverfew/Tanacetum } \\
\text { parthenium }\end{array}$ & 48.4 & 264.2 & 5.5 \\
\hline Green Tea Std sigma T5550 & 45.5 & 228.7 & 5.0 \\
\hline $\begin{array}{l}\text { Elecampane Root/Inula } \\
\text { helenium }\end{array}$ & 257.8 & 1276.0 & 4.9 \\
\hline Quercetin & 14.3 & 63.8 & 4.5 \\
\hline Commiphora myrrha resin & 127.1 & 5221.1 & 4.1 \\
\hline Amla/Phyllanthus emblica & 156.7 & 641.0 & 4.1 \\
\hline Herb de province & 203.4 & 793.2 & 3.9 \\
\hline $\begin{array}{l}\text { Turmeric Root/Curcuma } \\
\text { longa }\end{array}$ & 87.3 & 274.3 & 3.1 \\
\hline Biochanin A & 119.0 & 345.1 & 2.9 \\
\hline Trifala & 195.3 & 559.5 & 2.9 \\
\hline $\begin{array}{l}\text { Cinnamon/Cinnamomum } \\
\text { burmannii }\end{array}$ & 344.9 & 923.0 & $>2.6$ \\
\hline EGCG & 20.0 & 50.8 & 2.5 \\
\hline Bergamottin & 67.1 & 161.7 & 2.4 \\
\hline Osha Root/Ligusticum porteri & 43.4 & 104.1 & 2.4 \\
\hline Kalijiri Purple Fleablame & 58.0 & 130.0 & 2.2 \\
\hline Curcumin & 12.6 & 28.1 & 2.2 \\
\hline Rabdosia rubescens Herb & 104.9 & 220.3 & 2.1 \\
\hline White Sage/Salvia apiana & 62.0 & 129.5 & 2.1 \\
\hline $\begin{array}{l}\text { Blood Root/Sanguinaria } \\
\text { canadensis }\end{array}$ & 23.4 & 47.4 & 2.0 \\
\hline
\end{tabular}

The data represent $\mathrm{LC}_{50}$ values for toxicity and $\mathrm{IC}_{50}$ values for $\mathrm{NO2}$ - reduction both determined by regression analysis on a minimum of 6 concentrations, $(n=4)$. The ratio of $\mathrm{LC}_{50} / \mathrm{LC}_{50} \mu \mathrm{gg} / \mathrm{mL}$ is the $i \mathrm{El}$ (in- vitro efficacy index), where the greater the value the greater the confidence in the anti-inflammatory effects. The symbol [>] denotes an $\mathrm{EEI}$ value acquired on a maximum upper limit concentration being tested 
Table 2 Efficacy of natural anti-inflammatory compounds relative to cellular toxicity in LPS activated BV-2 cells BV-2 microglia cells $+1 \mu \mathrm{g} / \mathrm{mL}$ LPS: anti-inflammatory potency

\begin{tabular}{|c|c|c|c|}
\hline Substance & $\begin{array}{l}\text { Anti-inflammatory } \\
\mathrm{IC}_{50}(\mu \mathrm{g} / \mathrm{mL})\end{array}$ & $\begin{array}{l}\text { Toxicity } L_{50} \\
(\mu \mathrm{g} / \mathrm{mL})\end{array}$ & $\begin{array}{l}i \mathrm{EI}\left(\mathrm{LC}_{50} \mathrm{~d}\right. \\
\left.\mathrm{IC}_{50}\right)\end{array}$ \\
\hline Cardamonin & 1.6 & 265.0 & $>169.4$ \\
\hline Dexamethasone & 1.9 & 260.0 & $>136.8$ \\
\hline Bay Leaf/Laurus nobilis & 34.2 & 537.0 & $>15.7$ \\
\hline Quercetin & 27.8 & 250.0 & $>8.9$ \\
\hline Apicidin & 0.0 & 0.6 & 65.5 \\
\hline L-N-lysine dihydrochloride & 4.2 & 247.2 & 58.8 \\
\hline $\begin{array}{l}\text { Elecampane Root/Inula } \\
\text { helenium }\end{array}$ & 154.4 & 1486.0 & 35.7 \\
\hline $\begin{array}{l}\text { Ashwagandha/Withania } \\
\text { somnifera }\end{array}$ & 166.4 & 2848.3 & 17.1 \\
\hline Hydrocortisone & 13.0 & 219.2 & 16.9 \\
\hline Apigenin & 25.2 & 337.0 & 13.4 \\
\hline Optilgold & 9.4 & 113.6 & 12.1 \\
\hline Biochanin A & 33.7 & 369.2 & 10.9 \\
\hline $\begin{array}{l}\text { Tansy Herb/Tanacetum } \\
\text { vulgare }\end{array}$ & 143.0 & 1302.1 & 9.1 \\
\hline $\begin{array}{l}\text { Feverfew/Tanacetum } \\
\text { parthenium }\end{array}$ & 28.2 & 230.2 & 8.2 \\
\hline $\begin{array}{l}\text { Centipeda/Centipeda } \\
\text { minima }\end{array}$ & 258.4 & 2105.2 & 8.1 \\
\hline $\begin{array}{l}\text { Osha Root/Ligusticum } \\
\text { porteri }\end{array}$ & 29.5 & 203.4 & 6.9 \\
\hline Eupatorin & 39.3 & 265.2 & 6.7 \\
\hline $\begin{array}{l}\text { Turmeric Root/Curcuma } \\
\text { longa }\end{array}$ & 74.4 & 498.9 & 6.7 \\
\hline Herb de province & 167.2 & 1115.3 & 6.7 \\
\hline $\begin{array}{l}\text { Granati peel/Punica } \\
\text { granatum rind }\end{array}$ & 75.7 & 439.1 & 5.8 \\
\hline Rabdosia rubescens Herb & 34.5 & 192.7 & 5.6 \\
\hline $\begin{array}{l}\text { Rosemary Lf/Rosmarinus } \\
\text { officinali }\end{array}$ & 43.0 & 214.8 & 5.0 \\
\hline Trifala & 88.3 & 408.8 & 4.6 \\
\hline Green Tea Std Sigma T5550 & 38.0 & 169.7 & 4.5 \\
\hline Curcumin & 10.2 & 43.2 & 4.2 \\
\hline Myrrh/Commiphora myrrha & 31.8 & 132.8 & 4.2 \\
\hline Clove/Syzygium aromaticum & 149.0 & 615.1 & 4.1 \\
\hline Indomethacin & 17.9 & 67.2 & 3.7 \\
\hline Sage leaf/Salvia officinalis & 80.3 & 298.4 & 3.7 \\
\hline Amla/Phyllanthus emblica & 206.1 & 736.1 & 3.6 \\
\hline White Sage/Salvia apiana & 79.2 & 282.0 & 3.6 \\
\hline Ganthoda & 168.3 & 563.7 & 3.3 \\
\hline Succinum Resin & 20.1 & 56.3 & 2.8 \\
\hline Genistein & 5.6 & 14.7 & 2.6 \\
\hline Baicalein & 7.8 & 20.1 & 2.6 \\
\hline Butein & 1.2 & 2.9 & 2.3 \\
\hline
\end{tabular}

Table 2 Efficacy of natural anti-inflammatory compounds relative to cellular toxicity in LPS activated BV-2 cells (Continued)

\begin{tabular}{llll}
\hline $\begin{array}{l}\text { Maddar root/Rubia } \\
\text { tinctorum }\end{array}$ & 59.2 & 135.0 & 2.3 \\
$\begin{array}{l}\text { Yerba Santa Lf/E. } \\
\text { californicum }\end{array}$ & 18.3 & 41.4 & 2.3 \\
$\begin{array}{l}\text { EGCG } \\
\text { Phloretin }\end{array}$ & 11.3 & 24.8 & 2.2 \\
$\begin{array}{l}\text { Frankincense/Boswellia } \\
\text { carterii }\end{array}$ & 17.2 & 37.8 & 2.2 \\
$\begin{array}{l}\text { Fisetin } \\
\text { Piperine }\end{array}$ & 2.3 & 32.5 & 2.1 \\
Javentri Powder & 36.2 & 4.7 & 2.1 \\
$\begin{array}{l}\text { Bergamottin } \\
\text { Cinnamon/Cinnamomum } \\
\text { burmann }\end{array}$ & 16.5 & 75.1 & 2.1 \\
\hline
\end{tabular}

The data represent $\mathrm{LC} \mathrm{C}_{50}$ values for toxicity and $\mathrm{IC}_{50}$ values for $\mathrm{NO2}$ - reduction both determined by regression analysis on a minimum of 6 concentrations, $(n=4)$. The ratio of $\mathrm{LC}_{50} / \mathrm{IC}_{50} \mu \mathrm{g} / \mathrm{mL}$ is the $i \mathrm{El}$ (in- vitro efficacy index), where the greater the value the greater the confidence in the anti-inflammatory effects. The symbol $[>]$ denotes an $i$ El value acquired on a maximum upper limit concentration being tested

by Tukey post hoc means comparison test, or a Student's $\mathrm{t}$ test. $\mathrm{IC}_{50} \mathrm{~s}$ were determined by regression analysis using Origin Software (Origin Lab, Northampton, MA).

\section{Results \\ Validation}

Validation studies were conducted to determine profiled cytokine differentials in LPS activated RAW 264.7 (Fig. 1) and BV-2 cells (Fig. 2), respectively - using semi quantitative antibody microarrays, which were run in triplicate. The representative panel shows both cell lines exposed to LPS prompted the greater release of MCP-1, GCSF, MIP1a, MIP1g and MIP-2, sTNFR1/11, RANTES and IL-6. Quantitative analysis of IL-6 was corroborated by ELISA (Fig. 3), and iNOS protein expression was evaluated by ICC (Fig. 4b) and NO2- release using the Griess Reagent (Fig. 4a), the latter of which was reduced in the presence of iNOS inhibitor (L-NIL).

\section{Screening}

The initial HTP screening was conducted using a natural plant library housing over 1400 extracts including: 1) Plants: seeds, fruits, vegetables and herbs (of diverse ethnic nature including Chinese, Egyptian, Indian etc.) 2) Natural derived chemicals/polyphenolics 3) Metabolic Substrates: amino acids, vitamins and energy intermediates such as organic acids, glycolytic intermediates and 4) Reference NSAID and steroidal anti-inflammatory drugs. The preliminary screen was conducted to assess reduction of NO2- in LPS activated cells [equal to or less than $230 \mu \mathrm{g} / \mathrm{mL}$ ] for all compounds (Fig. 5a). 
Substances that attenuated $\mathrm{NO}_{2}-$ at less than $50 \%$ of the $1^{\text {st }}$ tier starting concentrations, were re-evaluated over a dose range where $\mathrm{LC}_{50 \text { s }}$ (cytotoxicity) and $\mathrm{IC}_{50 \mathrm{~s}}$ (NO2-) were simultaneously evaluated (Fig. 5b, c). From the linear regression, $\mathrm{LC}_{50}, \mathrm{IC}_{50 \text { s }}$ concentrations were determined and in-vitro efficacy index (iEI) was calculated by the ratio value : $\mathrm{LC}_{50} / \mathrm{IC}_{50}$. The higher the ratio, the greater confidence of true anti-inflammatory effects, not attributable to cell death. All $i$ EI values are presented in Table 1 for RAW 264.7 cells/Table 2 for BV-2 cells, with matching logarithmic scatter-plots (Figs.6 and 7). Figure 8 shows a sample of NO2-/viability dose response data, with corresponding immunochemical imaging for iNOS in RAW 264.7 cells, where supernatant was evaluated for IL-6. The data from these experiments show that L-NIL, while capable of inhibiting the catalytic function of iNOS, was not an anti-inflammatory in the true sense. L-NIL suppressed $\mathrm{NO}_{2}$ - but had no effects on cytokine release or expression of iNOS. Most lead compounds that reduced NO2- in both cell lines at sub-lethal concentrations ( $2 \mathrm{x} \mathrm{IC}_{50}$ for NO2-inhibition) which corresponded to a reduction of IL-6 in sample supernatant (Fig. 9). The antimicrobial effects of natural products on the survival of E.coli 0157:H7 (1x10 6 CFU/mL) were then evaluated. The data show only a select few have therapeutic potency relative to penicillin/streptomycin (Table 3), colloidal silver being the most effective (Fig. 10). The findings from this study delineate the most potent anti-inflammatory/and antibacterial natural compounds, when conducted in a uniform controlled fashion in these particular models.

\section{Discussion}

The data from this study establish several findings including $[\mathrm{A}]$ uncorroborated anti-inflammatory/

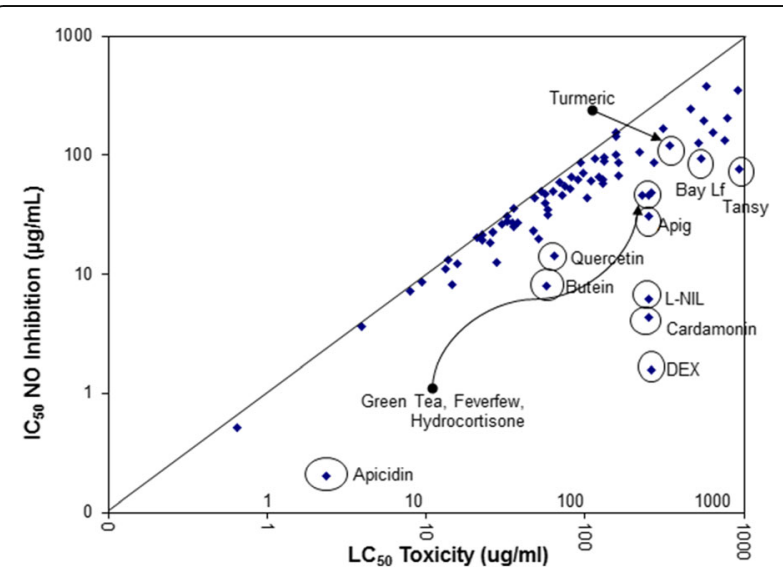

Fig. 6 In-vitro efficacy scatter-plot for $\mathrm{NO}_{2}$-, inhibition vs. cell toxicity in RAW 264.7 cells. The data are presented as $L C_{50}$ (toxicity) vs. IC 50 (iNOS inhibition) determined from a regression analysis on a minimum of 6 concentrations

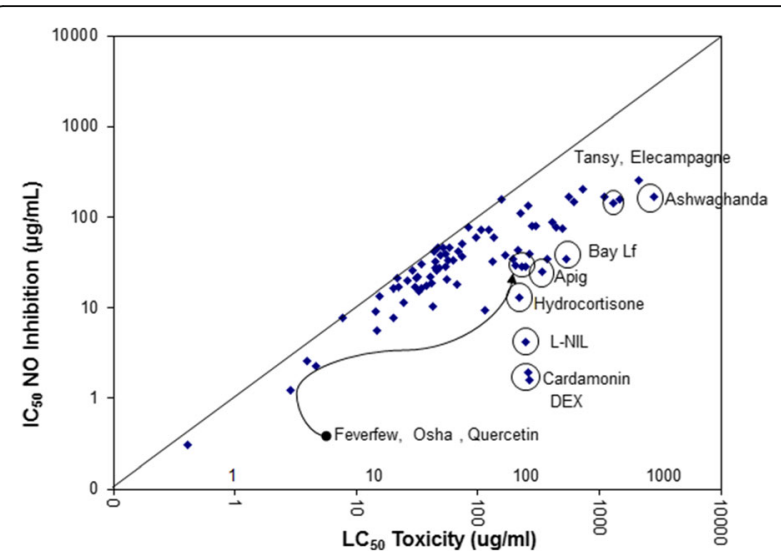

Fig. 7 In-vitro efficacy scatter-plot for $\mathrm{NO}_{2}$, inhibition vs. cell toxicity in BV-2 cells. The data are presented as $L C_{50}$ (toxicity) vs. $I_{50}$ (iNOS inhibition) determined from a regression analysis on a minimum of 6 concentrations

antimicrobial effects for over a thousand natural compounds at concentrations less than $230 \mu \mathrm{g} / \mathrm{mL}$ using this model; [B] corroborating data of existing work by other research groups regarding anti-inflammatory effects of green tea, curcumin, turmeric and rosemary ; and antimicrobial properties of green tea, its catechins, Chinese gallnut, gallic acid plant derived anti-fungal agents (cotton/gossypol) or silver nanoparticle dispersions [28-37]. Lastly; [C] this work provides new evidence on some lesser acknowledged herbs to which historical medicinal value has been attributed, but little research has been documented. Some of these include the following.

Elecampane (Inula helenium) (IH) has extensive historical medicinal value, where its use dates back to the Iron Age (c. 800-450 B.C.) throughout the third century B.C. to 79 A.D. also mentioned by Pliny and further corroborated in the Chilandar Medical Codex (13th or 14th centuries A.D.) [38]. Within the last century, scientific documentation is somewhat sparse on this herb having primarily focused on its ability to cause allergic dermatitis or act as an anti-cancer agent attributable to the content of alantolactone and isoalantolactone [39-44]. Meager work has been performed investigating the effect of $\mathrm{IH}$ on sepsis or age relate chronic inflammatory conditions. Although meager research has been conducted in $\mathrm{IH}$, the findings presented here are in alignment with existing researchers who have reported its capacity to attenuate iNOS/NO2-, COX-2/PGE2, HMGB1 release and NF- $\mathrm{kB}$ in LPS-activated RAW 264.7 cells or phorbol activated $\mathrm{T}$ cells [45-48]. Interestingly, although we did not find $\mathrm{IH}$ to have significant antimicrobial effects on E.coli $0157: \mathrm{H} 7\left(1 \times 10^{6} \mathrm{CFU} / \mathrm{mL}\right)$ at the low concentrations criteria used in this study, others have reported its capacity to destroy invasive pathogens such as Staphylococcus aureus/methicillin-resistant (MRSA) gram- 


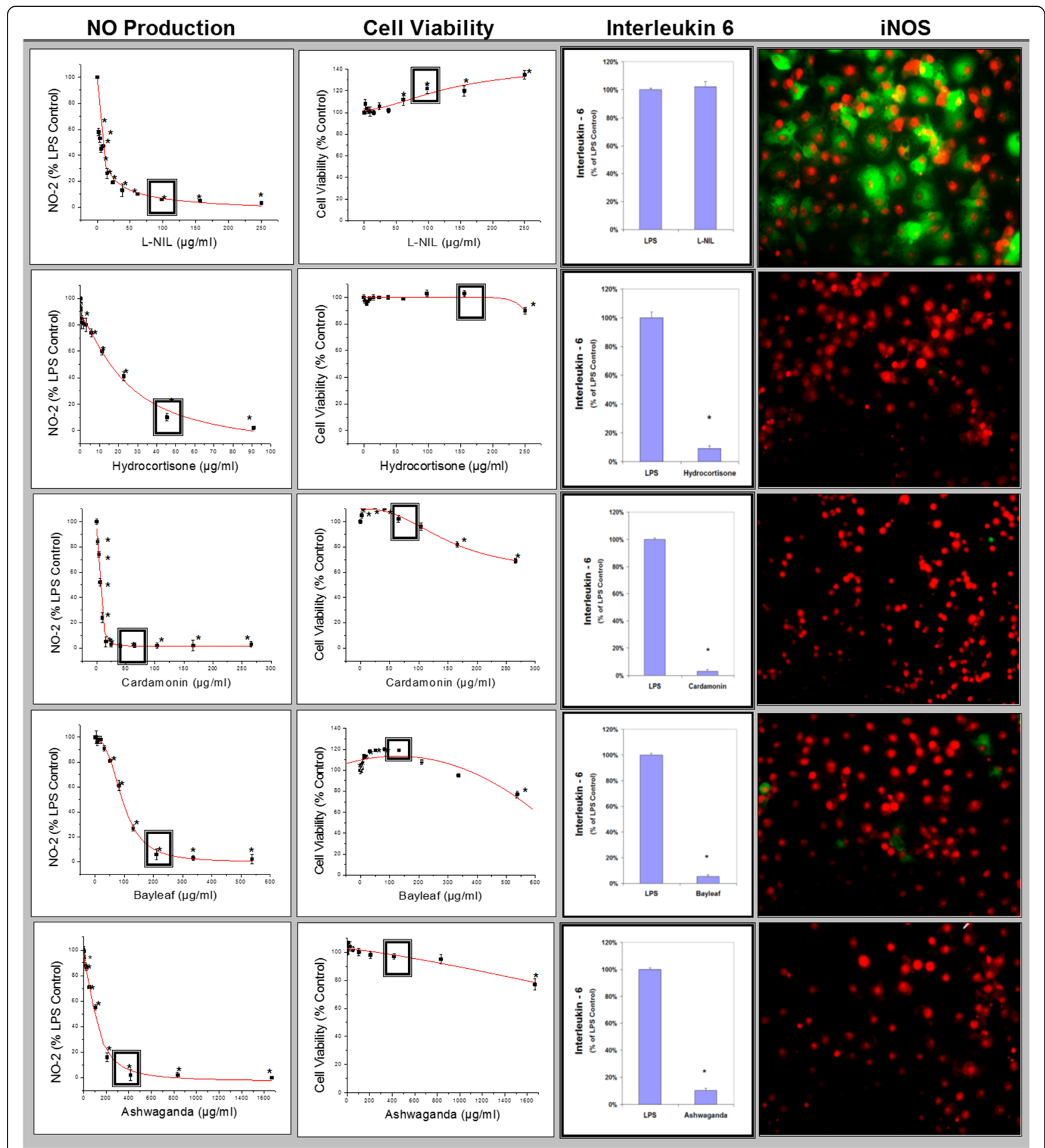

Fig. 8 Linear regression profiles for NO2- inhibition and toxicity in RAW 264.7 cells, by which $L C_{50 s}$ and $I C_{50}$ s were calculated for all compounds,

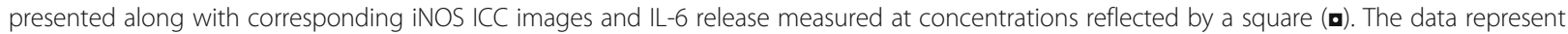
NO2- and viability (\% LPS Control), presented as the Mean \pm S.E.M, $n=4$. Statistical difference from the Controls were determined by a one-way ANOVA, followed by a Tukey post - hoc test * $P<0.05$ and IL- 6 from controls by a student's t-test* $P<0.05$

positive bacteria, yeasts parasites and Mycobacterium tuberculosis [42, 49-53]. These studies suggest IH as being somewhat promising for attenuating inflammation arising from diverse infective or inflammatory insults.
The data from this work also show that fresh dried ethanol extracts of Bay leaf (BL) (Laurus nobilis) contains anti-inflammatory properties [54, 55]. Previous work by others demonstrates the oil (not aqueous) 


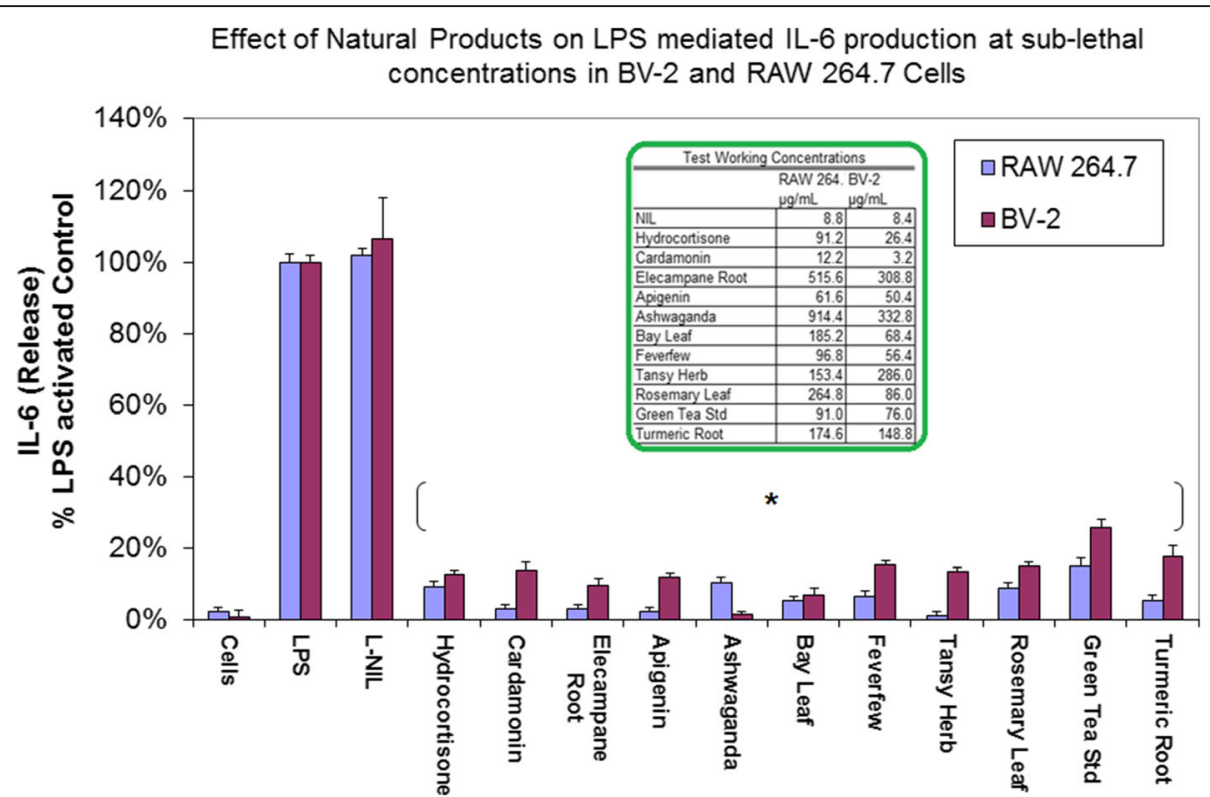

Fig. 9 Effects of lead anti-inflammatory products on IL-6 release in LPS treated BV-2 and RAW 264.7 cells. The data represents IL-6 (as \% LPS Control) and expressed as the Mean \pm S.E.M., $n=3$. Differences between activated cells \pm natural compounds at sub-lethal dose were determined by a student's $T$ test $\left(^{*}\right) P<0.001$

extracts to contain antimicrobial/food preserving properties due to cineole, eugenol, pinene, eucalyptol, linalool, carvacrol and $\alpha$-terpinenyl acetate all evidentially toxic to Gram-positive bacteria (Staphylococcus aureus/ pyogenes) and fungi (Candida albicans, Aspergillus fumigatus) [56-59]. Again, regarding the aqueous extract of $\mathrm{BL}$, our work corroborates the work of others having reported the capacity to attenuate LPS mediated microglia/macrophage activation thought to be attributable to its sesquiterpene content $[60,61]$. These type of substances are thought to be beneficial in chronic age related degeneration, by not only reducing inflammation but also blocking neurotoxicity of $\mathrm{AD}$ pathological $\mathrm{A} \beta$ (25-35)-component fragments [62].

Another herbal extract used in the current study to which little data exists is Centipeda minima (CM). CM has previously been reported to contain high levels of helenalin with the capacity to LPS mediated elevation of $\mathrm{NO}_{2}-, \mathrm{TNF}-\alpha$, IL-1b, iNOS and cyclooxygenase- 2 in macrophages [63]. CM also demonstrates the capacity to attenuate tissue injury in-vivo involving inflammation such as carrageen paw edema and liver fibrosis [63-65]. Although we did not find CM to have significant antimicrobial effects on E.coli 0157:H7 (1 x $\left.10^{6} \mathrm{CFU} / \mathrm{mL}\right)$ at the low concentration criteria used in this study, others have reported its capacity to kill Enterobacter aerogenes, Staphylococcus aureus, Yersinia enterocolitica and Bacillus subtilis [66, 67].

Feverfew (Tanacetum parthenium) (TP) is another rarely evaluated herb which long been reported to treat inflammatory conditions including psoriasis, allergies, arthritis, asthma and particularly migraines [68]. TP derived sesquiterpene lactones such as parthenolide are believed to be responsible for observed anti-inflammatory effects in animal models of carrageenan-induced edema, osteoarthritis, colitis cystic fibrosis and phorbol triggered mouse-ear edema [69-73]. TP constituents also antagonize toll-like receptors, Akt/mTOR and NF-kB pathways and block the downstream release of cytokines $[74,75]$. Like the present study, previous research reports also corroborate capacity to reduce LPS activation of BV-2 cells and RAW 264.7 cells alike [76, 77]. There is also an antinociceptive aspect to feverfew commonly reported, having benefit to ameliorate pain associated with diabetic peripheral neuropathy [78].

The use of tansy (Tanacetum vulgare) (TV) as a medicinal plant was reported dating back to the 8th century A.D., when the Benedictine monks used it to treat intestinal worms, ameliorate digestive problems, fevers and sores. Interestingly, both feverfew and tansy have in common hyper allergenic potential due to parthenolide $[79,80]$. Tansy is also rich in flavonoid glycosides, 7-O-glucosides of apigenin, luteolin, scutellarein and 6- hydroxyluteolin, chrysoeriol and eriodictyol as well as aglycones, hispidulin, nepetin, eupatilin, jaceosidin, pectolinarigenin and axillarin [81]. The oil contains 1,8-cineole and $\beta$-thujone as a major constituent along with carveol, umbellulone, davanone, dihydrocarvone, chrysanthenol, borneol and myrtenol [82-85]. 
Table 3 Efficacy of CAM antibacterial compounds on survival of E.coli 0157:H7 (1×106 CFU/ml) @ $8 \mathrm{~h}$ in $31^{\circ} \mathrm{C}$

\begin{tabular}{|c|c|c|}
\hline \multicolumn{3}{|c|}{ Anti-bacterial effects of natural compounds on E. coli 0157:H7 survival } \\
\hline Compound & $\mathrm{LC}_{50}$ & Units \\
\hline Penicillin/Streptomycin & 0.01 & 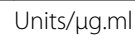 \\
\hline Cholloidal Silver-Argentym $23^{\oplus}$ & 0.02 & $\mu \mathrm{g} / \mathrm{ml}$ \\
\hline (+) Gossypol & 1.5 & $\mu \mathrm{g} / \mathrm{ml}$ \\
\hline Grapeseed Extract/Vitis Vinifera & 1.8 & $\mu \mathrm{g} / \mathrm{ml}$ \\
\hline Green Tea Extract/Camellia Sinensis & 2.0 & $\mu \mathrm{g} / \mathrm{ml}$ \\
\hline (-)-Epigallocatechin gallate & 3.7 & $\mu \mathrm{g} / \mathrm{ml}$ \\
\hline Doxorubin hydrochloride & 5.4 & $\mu \mathrm{g} / \mathrm{ml}$ \\
\hline Gallic Acid & 8.4 & $\mu \mathrm{g} / \mathrm{ml}$ \\
\hline Caffeic Acid & 10.1 & $\mu \mathrm{g} / \mathrm{ml}$ \\
\hline Chinese Gallnut & 10.4 & $\mu \mathrm{g} / \mathrm{ml}$ \\
\hline Babul Chall Bark/Acacia arabica & 13.4 & $\mu \mathrm{g} / \mathrm{ml}$ \\
\hline Polyphenon 60 & 14.1 & $\mu \mathrm{g} / \mathrm{ml}$ \\
\hline Uva Ursi/Arctostaphylos uva ursi & 19.1 & $\mu \mathrm{g} / \mathrm{ml}$ \\
\hline Arjun/Terminalia arjuna & 23.8 & $\mu \mathrm{g} / \mathrm{ml}$ \\
\hline Balm of Gilead Bud/Populus candicans & 26.7 & $\mu \mathrm{g} / \mathrm{ml}$ \\
\hline Bayberry Root/Morella cerifera & 28.5 & $\mu \mathrm{g} / \mathrm{ml}$ \\
\hline Blood Root/Sanguinaria canadensis/ & 33.5 & $\mu \mathrm{g} / \mathrm{ml}$ \\
\hline (-)-Gallocatechin & 35.8 & $\mu \mathrm{g} / \mathrm{ml}$ \\
\hline 2-D08 & 37.0 & $\mu \mathrm{g} / \mathrm{ml}$ \\
\hline Glyoxal Acid & 39.6 & $\mu \mathrm{g} / \mathrm{ml}$ \\
\hline Scutellarian & 42.0 & $\mu \mathrm{g} / \mathrm{ml}$ \\
\hline Kokum Black/Garcinia Indica & 47.5 & $\mu \mathrm{g} / \mathrm{ml}$ \\
\hline Indole & 47.5 & $\mu \mathrm{g} / \mathrm{ml}$ \\
\hline Trifala & 47.7 & $\mu \mathrm{g} / \mathrm{ml}$ \\
\hline CraneSbill Root/Geranium maculatum & 51.6 & $\mu \mathrm{g} / \mathrm{ml}$ \\
\hline Shi Liu Pi (Granati Peel) & 60.4 & $\mu \mathrm{g} / \mathrm{ml}$ \\
\hline Catuaba Bark/Trichilia Catigua & 63.4 & $\mu \mathrm{g} / \mathrm{ml}$ \\
\hline Chapparal/Larrea tridentata & 73.6 & $\mu \mathrm{g} / \mathrm{ml}$ \\
\hline Thymol & 92.0 & $\mu \mathrm{g} / \mathrm{ml}$ \\
\hline Esculetin & 93.3 & $\mu \mathrm{g} / \mathrm{ml}$ \\
\hline Epicatechin & 114.0 & $\mu \mathrm{g} / \mathrm{ml}$ \\
\hline Piperonal & 115.1 & $\mu \mathrm{g} / \mathrm{ml}$ \\
\hline (+)-Catechin & 173.0 & $\mu \mathrm{g} / \mathrm{ml}$ \\
\hline
\end{tabular}

The data represents $\mathrm{LC}_{50}$ values determined by regression analysis, on a minimum of 6 concentrations, $(n=4)$

Ashwagandha (Withania somnifera) (WS) is a highly studied herb with a plethora of known health benefits, in particular for prevention of cardiovascular disease. Its primary bioactive compound (Withaferin A) directly inhibits $\beta 1$-adrenergic receptors, HMG-CoA, angiotensinogenconverting enzyme, total cholesterol, triglycerides, low density lipoprotein and elevation of protective high density lipoproteins and endogenous antioxidant systems $[86,87]$. In animal models, WS prevents isoproterenol induced myocardial infarction, stroke distal middle cerebral

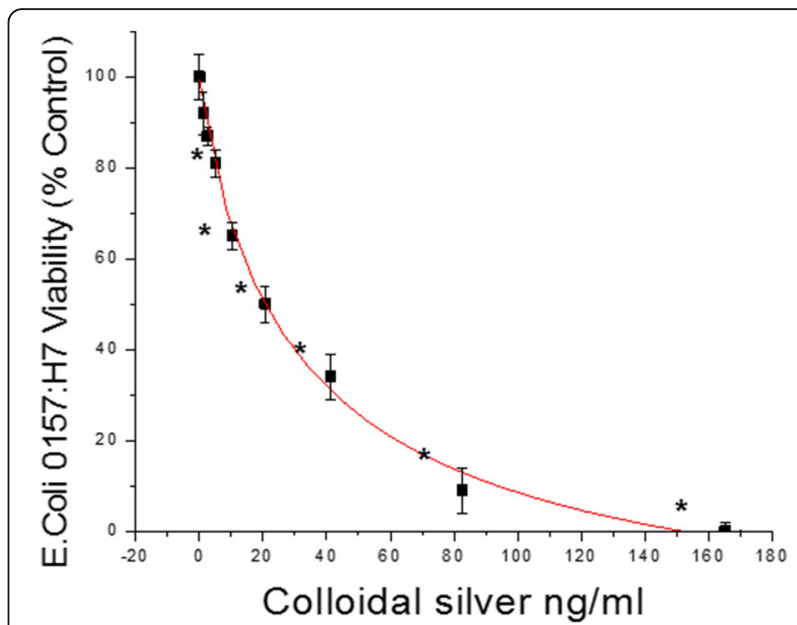

Fig. 10 The effect of colloidal Silver-Argentyn $23^{\circ}$ on the survival

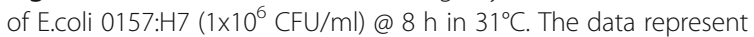
viability (\% Control), presented as the Mean \pm S.E.M, $n=4$. Statistical differences from the Control were determined by a one-way ANOVA, using the Tukey post - hoc test. ${ }^{*} P<0.05$

artery occlusion and monocrotaline induced pulmonary hypertension in rats [88-91]. With respect to the immune system, WS can attenuate mitogen induced T/B-cell activation, secretion of Th1 and Th2 cytokines and inhibit NF- $\kappa \mathrm{B}$ nuclear translocation in lymphocytes [92]. These immunomodulating effects of WS are also reported invitro for systemic LPS or $E$. coli administration in mammals, where there is a reduction in neutrophil tissue infiltration $[93,94]$ as well as tissue damage and pain associated with rheumatoid arthritis [95-97]. Ashwagandha is also an anti-infective agent lethal to gram-positive bacteria/cocci such as methicillin resistant Staphylococcus aureus and Enterococcus, respectively [98]. The data in this study ranks, validates and confirms pre-existing research showing significant antimicrobial effects of green tea EGCG polyphenon-60 (PP-60) Acacia arabica,grapeseed extract, caffeic, gallic acid, chapparal (Larrea tridentata) [99-109], where little has been investigated on antimicrobial herbs such as balm of Gilead Bud (Populus candicans), an herb of great historical significance with observed antibacterial and anti-inflammatory properties.

\section{Conclusion}

In conclusion, the data obtained in this work affords general information on validated CAM anti-inflammatory and antimicrobial compounds and relative potency at sub lethal concentrations in LPS activated BV-2 and RAW 264.7 cells. Moreover, the data obtained also provide relative lethal potency of CAMs against the growth of E.coli 0157:H7. These findings can serve as a guide for future examination of specific CAM based herbal/nutraceutical anti-inflammatory/antimicrobial modalities for use in prevention or treatment of disease. 


\section{Abbreviations}

ANOVA: One-way analysis of variance; CAMs: Complementary and alternative medicines; CM: Centipeda minima; CNS: Central nervous system; COX2: Cyclooxygenase-2; DMEM: Dulbecco's modified eagle medium; EGCG: (-)-epigallocatechin gallate; ELISA: Enzyme-linked immunosorbent assay; GCSF: Granulocyte-colony stimulating factor; HMGB1: High mobility group box 1 protein; HTP: High through put iEl: in-vitro efficacy index; IH: Inula helenium; INOS: Inducible nitric oxide; LPS: Lipopolysaccharide; MSRA: Methicillin-resistant; NO2-: Nitrite; NSAID: Non-steroidal anti-inflammatory drugs; PBS: phosphate buffered saline; RANTES: Regulated on activation, normal T cell expressed and secreted; TP: Tanacetum parthenium (Feverfew); TV: Tanacetum vulgare (Tansy); WS: Withania somnifera (Ashwagandha)

\section{Acknowledgments}

We wish to thank undergraduate students for sample prep and diverse project tasks: Ms. Swan and Marquis Cromartie, as well as the STEM Summer Students- Leandria Harvey and Gabrielle Bradley and their mentor Dr. Tiffany Ardley.

\section{Funding}

This research was supported by the National Institute of Minority Health and Health Disparities of the National Institutes of Health through Grant Number 8 G12MD007582-28 and Grant Number 1P20 MD006738-01.

\section{Availability of data and materials}

Materials and data of this study are available to other researchers upon request.

\section{Authors' contributions}

EAM was responsible for overview, planning, carrying out basic natural product screenings, confirmation of ELISAS, imaging and manuscript preparation. NL, MD, HW and LT were responsible for planning, overseeing and carrying out the microbial HTP screenings, DB, PM and ET were responsible for cytokine profiling and KFAS was in charge of project planning, overview and manuscript preparation. All authors read and approved the final manuscript.

\section{Competing interest}

The authors declare that they have no competing interests.

\section{Consent for publication}

NA.

\section{Ethics approval and consent to participate}

NA.

\section{Author details}

${ }^{1}$ College of Pharmacy \& Pharmaceutical Sciences, Florida A\&M University, Room 104 Dyson Pharmacy Building, 1520 ML King Blvd, Tallahassee, FL 32307, USA. ${ }^{2}$ School of Environment, Florida A\&M University, Tallahassee, FL 32307, USA. ${ }^{3}$ College of Science \& Technology, Florida A\&M University, Tallahassee, FL 32307, USA.

Received: 24 April 2016 Accepted: 29 October 2016

Published online: 15 November 2016

\section{References}

1. Hostinar CE, Ross KM, Chen E, Miller GE. Modeling the association between lifecourse socioeconomic disadvantage and systemic inflammation in healthy adults: The role of self-control. Health Psychol. 2015;34(6):580-90.

2. Hebert JR, Braun KL, Kaholokula JK, Armstead CA, Burch JB, Thompson B. Considering the Role of Stress in Populations of High-Risk, Underserved Community Networks Program Centers. Prog Community Health Partnersh. 2015;9(Suppl):71-82.

3. Yang YH, Rajaiah R, Lee DY, Ma Z, Yu H, Fong HH, Lao L, Berman BM, Moudgil KD. Suppression of ongoing experimental arthritis by a chinese herbal formula (huo-luo-xiao-ling dan) involves changes in antigen-induced immunological and biochemical mediators of inflammation. Evid Based Complement Alternat Med. 2011;2011:642027.
4. Vojdani A, Lambert J, Kellermann G. The Role of Th17 in Neuroimmune Disorders: A Target for CAM Therapy. Part III. Evid Based Complement Alternat Med. 2011;2011:548086.

5. Kes VB, Cesarik M, Matovina LZ, Zavoreo I, Coric L, Drnasin S, Demarin V. The role of complementary and alternative medicine in therapy of multiple sclerosis. Acta Clin Croat. 2013;52(4):464-71.

6. Lissat A, Joerschke M, Shinde DA, Braunschweig T, Meier A, Makowska A, Bortnick R, Henneke P, Herget G, Gorr TA, et al. IL6 secreted by Ewing sarcoma tumor microenvironment confers anti-apoptotic and cell-disseminating paracrine responses in Ewing sarcoma cells. BMC Cancer. 2015;15:552.

7. Yao H, Chen Y, Zhang L, He X, Lian L, Wu X, Lan P. Carnosol inhibits cell adhesion molecules and chemokine expression by tumor necrosis factor-alpha in human umbilical vein endothelial cells through the nuclear factor-kappaB and mitogen-activated protein kinase pathways. Mol Med Rep. 2014:9(2):476-80.

8. Salaga M, Zatorski H, Sobczak M, Chen C, Fichna J. Chinese herbal medicines in the treatment of IBD and colorectal cancer: a review. Curr Treat Options Oncol. 2014;15(3):405-20.

9. Kwak S, Ku SK, Bae JS. Fisetin inhibits high-glucose-induced vascular inflammation in vitro and in vivo. Inflamm Res. 2014;63(9):779-87.

10. Weber GF, Chousterman BG, He S, Fenn AM, Nairz M, Anzai A, Brenner T, Uhle F, Iwamoto Y, Robbins CS, et al. Interleukin-3 amplifies acute inflammation and is a potential therapeutic target in sepsis. Science. 2015; 347(6227):1260-5

11. Martin I, Caban-Hernandez K, Figueroa-Santiago O, Espino AM. Fasciola hepatica fatty acid binding protein inhibits TLR4 activation and suppresses the inflammatory cytokines induced by lipopolysaccharide in vitro and in vivo. J Immunol. 2015;194(8):3924-36

12. Lee SK, Park YJ, Ko MJ, Wang Z, Lee HY, Choi YW, Bae YS. A novel natural compound from garlic (Allium sativum L.) with therapeutic effects against experimental polymicrobial sepsis. Biochem Biophys Res Commun. 2015; 464(3):774-9.

13. Barichello T, Generoso JS, Silvestre C, Costa CS, Carrodore MM, Cipriano AL, Michelon CM, Petronilho F, Dal-Pizzol F, Vilela MC, et al. Circulating concentrations, cerebral output of the CINC-1 and blood-brain barrier disruption in Wistar rats after pneumococcal meningitis induction. Eur J Clin Microbiol Infect Dis. 2012;31(8):2005-9.

14. Bessler H, Djaldetti R, Salman H, Bergman M, Djaldetti M. IL-1 beta, IL-2, IL-6 and TNF-alpha production by peripheral blood mononuclear cells from patients with Parkinson's disease. Biomed Pharmacother. 1999; 53(3):141-5

15. Blum-Degen D, Muller $T$, Kuhn W, Gerlach M, Przuntek H, Riederer P. Interleukin-1 beta and interleukin-6 are elevated in the cerebrospinal fluid of Alzheimer's and de novo Parkinson's disease patients. Neurosci Lett. 1995;202(1-2):17-20

16. Brodacki B, Staszewski J, Toczylowska B, Kozlowska E, Drela N, Chalimoniuk M, Stepien A. Serum interleukin (IL-2, IL-10, IL-6, IL-4), TNFalpha, and INFgamma concentrations are elevated in patients with atypical and idiopathic parkinsonism. Neurosci Lett. 2008;441(2):158-62.

17. Zhu L, Wang J, Wei T, Gao J, He H, Chang X, Yan T. Effects of Naringenin on inflammation in complete freund's adjuvant-induced arthritis by regulating Bax/BCl-2 balance. Inflammation. 2015;38(1):245-51.

18. Blasi E, Barluzzi R, Bocchini V, Mazzolla R, Bistoni F. Immortalization of murine microglial cells by a v-raf/v-myc carrying retrovirus. J Neuroimmunol. 1990; 27(2-3):229-37.

19. Evans SM, Casartelli A, Herreros E, Minnick DT, Day C, George E, Westmoreland C. Development of a high throughput in vitro toxicity screen predictive of high acute in vivo toxic potential. Toxicol In Vitro. 2001;15(4-5):579-84.

20. Zhang X, Luo W, Zhao W, Lu J, Chen X. Isocryptotanshinone Induced Apoptosis and Activated MAPK Signaling in Human Breast Cancer MCF-7 Cells. J Breast Cancer. 2015;18(2):112-8.

21. Huang WC, Hsu RM, Chi LM, Leu YL, Chang YS, Yu JS. Selective downregulation of EGF receptor and downstream MAPK pathway in human cancer cell lines by active components partially purified from the seeds of Livistona chinensis R. Brown Cancer Lett. 2007;248(1):137-46.

22. Amirghofran Z. Herbal medicines for immunosuppression. Iran J Allergy Asthma Immunol. 2012;11(2):111-9.

23. Pan HC, Jiang Q, Yu Y, Mei JP, Cui YK, Zhao WJ. Quercetin promotes cell apoptosis and inhibits the expression of MMP-9 and fibronectin via the AKT and ERK signalling pathways in human glioma cells. Neurochem Int. 2015; 80:60-71. 
24. Cheng YW, Chang CY, Lin KL, Hu CM, Lin CH, Kang JJ. Shikonin derivatives inhibited LPS-induced NOS in RAW 264.7 cells via downregulation of MAPK NF-kappaB signaling. J Ethnopharmacol. 2008;120(2):264-71.

25. Chen CC, Tsai PC, Wei BL, Chiou WF. 8-Prenylkaempferol suppresses inducible nitric oxide synthase expression through interfering with JNK-mediated AP-1 pathway in murine macrophages. Eur J Pharmacol. 2008;590(1-3):430-6.

26. Ci X, Liang X, Luo G, Yu Q, Li H, Wang D, Li R, Deng X. Regulation of inflammatory mediators in lipopolysaccharide-stimulated RAW 264.7 cells by 2"-hydroxy-3"-en-anhydroicaritin involves down-regulation of NF-kappaB and MAPK expression. Int Immunopharmacol. 2010;10(9):995-1002.

27. Cendan JC, Topping DL, Pruitt J, Snowdy S, Copeland 3rd EM, Lind DS. Inflammatory mediators stimulate arginine transport and arginine-derived nitric oxide production in a murine breast cancer cell line. J Surg Res. 1996;60(2):284-8.

28. Yang F, de Villiers WJ, McClain CJ, Varilek GW. Green tea polyphenols block endotoxin-induced tumor necrosis factor-production and lethality in a murine model. J Nutr. 1998;128(12):2334-40.

29. Chan MM, Fong D, Ho CT, Huang HI. Inhibition of inducible nitric oxide synthase gene expression and enzyme activity by epigallocatechin gallate, a natural product from green tea. Biochem Pharmacol. 1997;54(12):1281-6.

30. Senthil Kumaran V, Arulmathi K, Sundarapandiyan R, Kalaiselvi P. Attenuation of the inflammatory changes and lipid anomalies by epigallocatechin-3gallate in hypercholesterolemic diet fed aged rats. Exp Gerontol. 2009; 44(12):745-51.

31. Bengmark S, Mesa MD, Gil A. Plant-derived health: the effects of turmeric and curcuminoids. Nutr Hosp. 2009;24(3):273-81.

32. Al-Okbi SY. Nutraceuticals of anti-inflammatory activity as complementary therapy for rheumatoid arthritis. Toxicol Ind Health. 2014;30(8):738-49.

33. Liang W, Fernandes AP, Holmgren A, Li X, Zhong L. Bacterial thioredoxin and thioredoxin reductase as mediators for epigallocatechin 3-gallateinduced antimicrobial action. FEBS J. 2016;283(3):446-58.

34. Noormandi A, Dabaghzadeh F. Effects of green tea on Escherichia coli as a uropathogen. J Tradit Complement Med. 2015;5(1):15-20.

35. Shao D, Li J, Li J, Tang R, Liu L, Shi J, Huang Q, Yang H. Inhibition of Gallic Acid on the Growth and Biofilm Formation of Escherichia coli and Streptococcus mutans. J Food Sci. 2015;80(6):M1299-305.

36. Chen XY, Chen $Y$, Heinstein $P$, Davisson VJ. Cloning, expression, and characterization of (+)-delta-cadinene synthase: a catalyst for cotton phytoalexin biosynthesis. Arch Biochem Biophys. 1995;324(2):255-66

37. He M, Lu L, Zhang J, Li D. Immobilized Silver Nanoparticles on Chitosan with Special Surface State-Enhanced Antimicrobial Efficacy and Reduced Cytotoxicity. J Nanosci Nanotechnol. 2015;15(9):6435-43.

38. Al-Gammal SY. Elecampane and Job's disease. Bull Indian Inst Hist Med Hyderabad. 1998;28(1):7-11.

39. P'lankova ZP. Nugmanova ML: [Dermatitis caused by elecampane]. Vestn Dermatol Venerol. 1975;12:52-4.

40. Wang J, Zhao YM, Zhang B, Guo CY. Protective Effect of Total Phenolic Compounds from Inula helenium on Hydrogen Peroxide-induced Oxidative Stress in SH-SY5Y Cells. Indian J Pharm Sci. 2015;77(2):163-9.

41. Zhao YM, Wang J, Liu HB, Guo CY, Zhang WM. Microwave-assisted Extraction of Alantolactone and Isoalantolactone from Inula helenium. Indian J Pharm Sci. 2015;77(1):116-20.

42. Cantrell CL, Abate L, Fronczek FR, Franzblau SG, Quijano L, Fischer NH. Antimycobacterial eudesmanolides from Inula helenium and Rudbeckia subtomentosa. Planta Med. 1999;65(4):351-5.

43. Rasul A, Khan M, Ali M, Li J, Li X. Targeting apoptosis pathways in cancer with alantolactone and isoalantolactone. ScientificWorldJournal. 2013;2013: 248532.

44. Yang C, Yang J, Sun M, Yan J, Meng X, Ma T. Alantolactone inhibits growth of K562/adriamycin cells by downregulating Bcr/Abl and P-glycoprotein expression. IUBMB Life. 2013;65(5):435-44.

45. Cabronero MC, Campos E, Picazo JJ, Romero J. Evaluation of an agglutination method of latex particles sensitized for the detection of vaginal candidiasis. Med Clin (Barc). 1990;94(9):329-32.

46. Nesterova lu V, Zelenskaia KL, Vetoshkina TV, Aksinenko SG, Gorbacheva AV, Gorbatykh NA. Mechanisms of antistressor activity of Inula helenium preparations. Eksp Klin Farmakol. 2003;66(4):63-5.

47. Danilets MG, Belska NV, Bel'sky YP, Uchasova EG, Trophimova ES, Ligatcheva AA, Guriev AM, Belousov MV, Ahmedganov RR, Usubov MS, et al. Effects of plant water-soluble polysaccharides on the production of immunoglobulins $\mathrm{E}$ and $\mathrm{G} 1$ by lymphocytes of mice sensitized with ovalbumin. Bull Exp Biol Med. 2008;146(5):585-7.
48. Na BR, Kim HR, Kwon MS, Lee HS, Piragyte I, Choi EJ, Choi HK, Han WC, Lee $\mathrm{SH}$, Jun CD. Aplotaxene blocks T cell activation by modulation of protein kinase C-theta-dependent pathway. Food Chem Toxicol. 2013;62:23-31.

49. Radulovic NS, Denic MS, Stojanovic-Radic ZZ. Synthesis of small combinatorial libraries of natural products: identification and quantification of new long-chain 3-methyl-2-alkanones from the root essential oil of Inula helenium L. (Asteraceae). Phytochem Anal. 2014;25(1):75-80.

50. Gokbulut A, Ozhan O, Satilmis B, Batcioglu K, Gunal S, Sarer E. Antioxidant and antimicrobial activities, and phenolic compounds of selected Inula species from Turkey. Nat Prod Commun. 2013;8(4):475-8.

51. O'Shea S, Lucey B, Cotter L. In vitro activity of Inula helenium against clinical Staphylococcus aureus strains including MRSA. Br J Biomed Sci. 2009;66(4):186-9.

52. El Garhy MF, Mahmoud LH. Anthelminthic efficacy of traditional herbs on Ascaris lumbricoides. J Egypt Soc Parasitol. 2002;32(3):893-900.

53. Cantrell $\mathrm{CL}$, Fischer NH, Urbatsch L, McGuire MS, Franzblau SG. Antimycobacterial crude plant extracts from South, Central, and North America. Phytomedicine. 1998;5(2):137-45.

54. Kilic A, Hafizoglu H, Kollmannsberger H, Nitz S. Volatile constituents and key odorants in leaves, buds, flowers, and fruits of Laurus nobilis L. J Agric Food Chem. 2004;52(6):1601-6.

55. Yahyaa M, Matsuba Y, Brandt W, Doron-Faigenboim A, Bar E, McClain A, Davidovich-Rikanati R, Lewinsohn E, Pichersky E, Ibdah M. Identification, Functional Characterization, and Evolution of Terpene Synthases from a Basal Dicot. Plant Physiol. 2015;169(3):1683-97.

56. Marzouki H, Khaldi A, Marongiu B, Piras A, Harzallah-Skhiri F. Chemical polymorphism of essential oils from populations of Laurus nobilis grown on Tunisia. Algeria and France Nat Prod Commun. 2011;6(10): 1483-6.

57. Ramos C, Teixeira B, Batista I, Matos O, Serrano C, Neng NR, Nogueira JM, Nunes ML, Marques A. Antioxidant and antibacterial activity of essential oil and extracts of bay laurel Laurus nobilis Linnaeus (Lauraceae) from Portugal. Nat Prod Res. 2012;26(6):518-29.

58. Fukuyama N, Ino C, Suzuki Y, Kobayashi N, Hamamoto H, Sekimizu K, Orihara Y. Antimicrobial sesquiterpenoids from Laurus nobilis L. Nat Prod Res. 2011;25(14):1295-303.

59. Liu MH, Otsuka N, Noyori K, Shiota S, Ogawa W, Kuroda T, Hatano T, Tsuchiya T. Synergistic effect of kaempferol glycosides purified from Laurus nobilis and fluoroquinolones on methicillin-resistant Staphylococcus aureus. Biol Pharm Bull. 2009;32(3):489-92.

60. Chen $H$, Xie C, Wang $H$, Jin DQ, Li S, Wang M, Ren Q, Xu J, Ohizumi Y, Guo Y. Sesquiterpenes inhibiting the microglial activation from Laurus nobilis. J Agric Food Chem. 2014;62(20):4784-8.

61. De Marino S, Borbone N, Zollo F, lanaro A, Di Meglio P, lorizzi M. New sesquiterpene lactones from Laurus nobilis leaves as inhibitors of nitric oxide production. Planta Med. 2005;71(8):706-10.

62. Pacifico S, Gallicchio M, Lorenz P, Duckstein SM, Potenza N, Galasso S, Marciano S, Fiorentino A, Stintzing FC, Monaco P. Neuroprotective potential of Laurus nobilis antioxidant polyphenol-enriched leaf extracts. Chem Res Toxicol. 2014;27(4):611-26.

63. Huang SS, Chiu CS, Lin TH, Lee MM, Lee CY, Chang SJ, Hou WC, Huang GJ, Deng JS. Antioxidant and anti-inflammatory activities of aqueous extract of Centipeda minima. J Ethnopharmacol. 2013;147(2):395-405.

64. Qin RA, Mei X, Wan L, Shi JL, Shen YJ. Effects of the volatile oil of Centipeda minima on acute pleural effusion in rats induced by an intrapleural injection of car. Zhongguo Zhong Yao Za Zhi. 2005;30(15):1192-4.

65. Lin X, Zhang S, Huang R, Wei L, Tan S, Liang S, Tian Y, Wu X, Lu Z, Huang Q. Helenalin attenuates alcohol-induced hepatic fibrosis by enhancing ethanol metabolism, inhibiting oxidative stress and suppressing HSC activation. Fitoterapia. 2014:95:203-13.

66. Soetardjo Jr S, Jong PC, Ahmad MN, Lachimanan YL, Sreenivasan S. Chemical Composition and Biological Activity of the Centipeda minima (Asteraceae). Malays J Nutr. 2007;13(1):81-7.

67. Taylor RS, Towers GH. Antibacterial constituents of the Nepalese medicinal herb, Centipeda minima. Phytochemistry. 1998:47(4):631-4.

68. Murphy JJ, Heptinstall S, Mitchell JR. Randomised double-blind placebocontrolled trial of feverfew in migraine prevention. Lancet. 1988;2(8604): 189-92.

69. Zhao Y, Chen SJ, Wang JC, Niu HX, Jia QQ, Chen XW, Du XY, Lu L, Huang B, Zhang $\mathrm{Q}$, et al. Sesquiterpene lactones inhibit advanced oxidation protein product-induced MCP-1 expression in podocytes via an IKK/NF-kappaBdependent mechanism. Oxid Med Cell Longev. 2015;2015:934058. 
70. Di Cesare ML, Tenci B, Zanardelli M, Maidecchi A, Lugli A, Mattoli L, Ghelardini C. Widespread pain reliever profile of a flower extract of Tanacetum parthenium. Phytomedicine. 2015;22(7-8):752-8.

71. Zhao ZJ, Xiang JY, Liu L, Huang XL, Gan HT. Parthenolide, an inhibitor of the nuclear factor-kappaB pathway, ameliorates dextran sulfate sodium-induced colitis in mice. Int Immunopharmacol. 2012;12(1):169-74

72. Saadane A, Masters S, DiDonato J, Li J, Berger M. Parthenolide inhibits IkappaB kinase, NF-kappaB activation, and inflammatory response in cystic fibrosis cells and mice. Am J Respir Cell Mol Biol. 2007;36(6):728-36.

73. Schinella GR, Giner RM, Recio MC. Mordujovich de Buschiazzo P, Rios JL, Manez S: Anti-inflammatory effects of South American Tanacetum vulgare. J Pharm Pharmacol. 1998;50(9):1069-74.

74. Nam YJ, da Lee H, Lee MS, Lee CS. Sesquiterpene lactone parthenolide attenuates production of inflammatory mediators by suppressing the Tolllike receptor-4-mediated activation of the Akt, mTOR, and NF-kappaB pathways. Naunyn Schmiedebergs Arch Pharmacol. 2015;388(9):921-30.

75. Park SJ, Shin HJ, Youn HS. Parthenolide inhibits TRIF-dependent signaling pathway of Toll-like receptors in RAW264.7 macrophages. Mol Cells. 2011; 31(3):261-5.

76. Magni P, Ruscica M, Dozio E, Rizzi E, Beretta G, Maffei Facino R. Parthenolide inhibits the LPS-induced secretion of IL-6 and TNF-alpha and NF-kappaB nuclear translocation in BV-2 microglia. Phytother Res. 2012;26(9):1405-9.

77. Hwang D, Fischer NH, Jang BC, Tak H, Kim JK, Lee W. Inhibition of the expression of inducible cyclooxygenase and proinflammatory cytokines by sesquiterpene lactones in macrophages correlates with the inhibition of MAP kinases. Biochem Biophys Res Commun. 1996;226(3):810-8.

78. Galeotti N, Maidecchi A, Mattoli L, Burico M, Ghelardini C. St. John's Wort seed and feverfew flower extracts relieve painful diabetic neuropathy in a rat model of diabetes. Fitoterapia. 2014;92:23-33.

79. Salapovic H, Geier J, Reznicek G. Quantification of Sesquiterpene Lactones in Asteraceae Plant Extracts: Evaluation of their Allergenic Potential. Sci Pharm. 2013:81(3):807-18.

80. Jovanovic M, Poljacki M, Duran V, Vujanovic L, Sente R, Stojanovic S. Contact allergy to Compositae plants in patients with atopic dermatitis. Med Pregl. 2004;57(5-6):209-18.

81. Uehara A, Akiyama S, Iwashina T. Foliar flavonoids from Tanacetum vulgare var. boreale and their geographical variation. Nat Prod Commun. 2015;10(3): 403-5.

82. Piras A, Falconieri D, Bagdonaite E, Maxia A, Goncalves MJ, Cavaleiro C, Salgueiro L, Porcedda S. Chemical composition and antifungal activity of supercritical extract and essential oil of Tanacetum vulgare growing wild in Lithuania. Nat Prod Res. 2014;28(21):1906-9.

83. Godinho LS, de Carvalho LS A, de Castro CC B, Dias MM, Pinto Pde F, Crotti $A E$, Pinto PL, de Moraes J, Da Silva Filho AA. Anthelmintic activity of crude extract and essential oil of Tanacetum vulgare (Asteraceae) against adult worms of Schistosoma mansoni. Sci World J. 2014;2014:460342.

84. Formisano C, Senatore F, Bruno M, Rosselli S, Bellone G, Spadaro V. Essential oil composition of Tanacetum vulgare subsp. siculum (Guss.) Raimondo et Spadaro (Asteraceae) from Sicily. Nat Prod Commun. 2009;4(4):567-70.

85. Hethelyi $E$, Tetenyi $P$, Dabi E, Danos B. The role of mass spectrometry in medicinal plant research. Biomed Environ Mass Spectrom. 1987; 14(11):627-32

86. Ravindran R, Sharma N, Roy S, Thakur AR, Subhadra G, Sriram K, Devi J, Rajkumar J. Interaction studies of Withania somnifera's key metabolite Withaferin A with different receptors associated with cardiovascular disease. Curr Comput Aided Drug Des. 2015.

87. Shukla K, Dikshit P, Shukla R, Sharma S, Gambhir JK. Hypolipidemic and antioxidant activity of aqueous extract of fruit of Withania coagulans (Stocks) Dunal in cholesterol-fed hyperlipidemic rabbit model. Indian J Exp Biol. 2014;52(9):870-5.

88. Khalil Ml, Ahmmed I, Ahmed R, Tanvir EM, Afroz R, Paul S, Gan SH, Alam N. Amelioration of Isoproterenol-Induced Oxidative Damage in Rat Myocardium by Withania somnifera Leaf Extract. Biomed Res Int. 2015; 2015:624159.

89. Ahmad H, Khandelwal K, Samuel SS, Tripathi S, Mitra K, Sangwan RS, Shukla $R$, Dwivedi AK. Neuro-protective potential of a vesicular system of a standardized extract of a new chemotype of Withania somnifera Dunal (NMITLI118RT+) against cerebral stroke in rats. Drug Deliv. 2015;1-12.

90. Raghavan A, Shah ZA. Withania somnifera Improves Ischemic Stroke Outcomes by Attenuating PARP1-AIF-Mediated Caspase-Independent Apoptosis. Mol Neurobiol. 2015;52(3):1093-105.
91. Kaur G, Singh N, Samuel SS, Bora HK, Sharma S, Pachauri SD, Dwivedi AK, Siddiqui $\mathrm{HH}$, Hanif K. Withania somnifera shows a protective effect in monocrotaline-induced pulmonary hypertension. Pharm Biol. 2015;53(1): 147-57.

92. Gambhir L, Checker R, Sharma D, Thoh M, Patil A, Degani M, Gota V, Sandur SK. Thiol dependent NF-kappaB suppression and inhibition of T-cell mediated adaptive immune responses by a naturally occurring steroidal lactone Withaferin A. Toxicol Appl Pharmacol. 2015;289(2):297-312.

93. Gao S, Li H, Zhou XQ, You JB, Tu DN, Xia G, Jiang JX, Xin C. Withaferin A attenuates lipopolysaccharide-induced acute lung injury in neonatal rats. Cell Mol Biol (Noisy-le-grand). 2015;61(3):102-6.

94. El-Boshy Mel S, Abdalla OM, Risha A, Moustafa F. Effect of Withania somnifera Extracts on Some Selective Biochemical, Hematological, and Immunological Parameters in Guinea Pigs Experimental Infected with E. coli. ISRN Vet Sci. 2013:2013:153427.

95. Kumar G, Srivastava A, Sharma SK, Rao TD, Gupta YK. Efficacy \& safety evaluation of Ayurvedic treatment (Ashwagandha powder \& Sidh Makardhwaj) in rheumatoid arthritis patients: a pilot prospective study. Indian J Med Res. 2015;141(1):100-6.

96. Khan MA, Subramaneyaan M, Arora VK, Banerjee BD, Ahmed RS. Effect of Withania somnifera (Ashwagandha) root extract on amelioration of oxidative stress and autoantibodies production in collagen-induced arthritic rats. J Complement Integr Med. 2015;12(2):117-25.

97. Gupta A, Singh S. Evaluation of anti-inflammatory effect of Withania somnifera root on collagen-induced arthritis in rats. Pharm Biol. 2014;52(3): 308-20.

98. Bisht $\mathrm{P}$, Rawat V. Antibacterial activity of Withania somnifera against Grampositive isolates from pus samples. Ayu. 2014;35(3):330-2.

99. Zakir M, Sultan KB, Khan H, Ihsaanullah, Khan MA, Fazal H, Rauf A. Antimicrobial activity of different tea varieties available in Pakistan Pak J Pharm Sci. 2015:28(6):2091-4.

100. Klancnik A, Piskernik S, Bucar F, Vuckovic D, Mozina SS, Jersek B. Reduction of microbiological risk in minced meat by a combination of natural antimicrobials. J Sci Food Agric. 2014;94(13):2758-65.

101. Gupta S, Bansal R, Ali J, Gabrani R, Dang S. Development and characterization of polyphenon 60 and caffeine microemulsion for enhanced antibacterial activity. Biomed Res Int. 2014;2014:932017.

102. Tambekar DH, Khante BS, Chandak BR, Titare AS, Boralkar SS, Aghadte SN. Screening of antibacterial potentials of some medicinal plants from Melghat forest in India. Afr J Tradit Complement Altern Med. 2009;6(3):228-32.

103. Ahn J, Grun IU, Mustapha A. Antimicrobial and antioxidant activities of natural extracts in vitro and in ground beef. J Food Prot. 2004;67(1):148-55.

104. Vandal J, Abou-Zaid MM, Ferroni G, Leduc LG. Antimicrobial activity of natural products from the flora of Northern Ontario. Canada Pharm Biol. 2015;53(6):800-6.

105. Favela-Hernandez JM, Garcia A, Garza-Gonzalez E, Rivas-Galindo VM, Camacho-Corona MR. Antibacterial and antimycobacterial lignans and flavonoids from Larrea tridentata. Phytother Res. 2012:26(12):1957-60.

106. Pinho E, Ferreira IC, Barros L, Carvalho AM, Soares G, Henriques M. Antibacterial potential of northeastern Portugal wild plant extracts and respective phenolic compounds. Biomed Res Int. 2014;2014:814590.

107. Lopez-Nicolas R, Gonzalez-Bermudez CA, Ros-Berruezo G, Frontela-Saseta C. Influence of in vitro gastrointestinal digestion of fruit juices enriched with pine bark extract on intestinal microflora. Food Chem. 2014;157:14-9.

108. Li Z, Summanen PH, Komoriya T, Henning SM, Lee RP, Carlson E, Heber D, Finegold SM. Pomegranate ellagitannins stimulate growth of gut bacteria in vitro: Implications for prebiotic and metabolic effects. Anaerobe. 2015;34:164-8.

109. Valéria NL, Oliveira-Tintino CD, Santos ES, et al. Antimicrobial and enhancement of the antibiotic activity by phenolic compounds: Gallic acid, caffeic acid and pyrogallol. Microb Pathog. 2016:99:56-61. 